\title{
Introduction to Global Container Shipping Market
}

\author{
César Ducruet, CNRS
}

Hidekazu Itoh, Kwansei Gakuin University

\author{
In: Shibasaki R., Kato H., Ducruet C. (Eds.) (2020) Global Logistics Network \\ Modelling and Policy. Quantification and Analysis for International Freight, Elsevier,
} pp. 3-30.

\section{Introduction: Containerization and global logistics}

In $26^{\text {th }}$ April, 1956, an American land transporter named Malcom McLean started competing with freight railway companies on inter-state long distance transport in the US. He first navigated a hopped-up container ship from Newark, New Jersey, to Houston, Texas, along the US East Coast by his shipping company (later named Sea-Land). Maritime containers were acquired for two main purposes: 1) to reduce port handling costs by unitization (container "box") of cargo and 2) to reduce truck transport cost on long-distance delivery. Indeed, the container ship permitted cargo to deliver cargo through intermodal transport on land and sea (Levinson, 2006).

The strongest advantage of containerization was to provide a more efficient cargo handling on the docks. At this time, a container was mounted on a wagon for land transport, or current rollon/roll-off (Ro-Ro) shipping. However, because the system was initially inefficient due to the weight and space of wagons, container ships used cranes to handle the box between ship and yard. Finally, the Sea-Land company launched a modern full-container ship without crane onboard in 1966 to cross the Atlantic, as European ports such as Antwerp became able to handle containers in the late 1960s (Morel and Ducruet, 2015). After certain technological progress, gantry cranes were placed on berths to carry containers between ship and terminal, while chasee and trailer moved containers inside the container terminal.

Containerization helped reducing handling time on both sea and land sides. At the time of early containerization, the total duration of a round-trip in the Pacific Ocean between East Asia (e.g. Kobe, Japan) and North America (NA) (e.g. San Francisco, US East Coast) by conventional ship (general cargo) was about eighty days (35 days on sea, and 45 days on land) in 1956. However, in 1968, after full-container ships were launched, the total duration of a round-trip decreased to thirty days (23 days on sea, and 7 days) between Tokyo and Los Angeles (Hoshino, 1995). Containerization had contributed to delete temporal gaps between origin and destination along supply chains, while accelerating global trade and horizontal division of production. In 2017, because of slow steaming and multi-stops at hub-ports, most of round-trips' duration are currently 
35 days (five weeks) or 42 days (six weeks) on the route (International Transportation Handbook, 2017), as explained below.

Finally, maritime transport business had changed from labor-intensive to capital-intensive industry. For example, global major ports heavily invested in new gantry cranes for faster handling operations. In addition to container terminal development, container ships grown in size to achieve economies of scale. Indeed, after the introduction of over-Panamax ${ }^{1}$ vessels in 1988, shipping lines built ever-larger container ships (Table 3). Such vessels again needed investments on the terminal side to accommodate ship calls all over the world. Deeper container berths, megagantry cranes, and larger container yards became the norm for terminal operations. For instance, such cranes must be cover 24 lines for the beam of 18,000 TEUs class container ships today.

Such operational and technological changes are both causes and consequences of wider global economic (e.g. manufacturing shifts) dynamics affecting the global port hierarchy, as seen with Table 1 for the period 1975-2016. In 1975, most of the top ranked container ports were North American, European and Japanese due to the provision, in the "Triade" (Ohmae, 1985), of container berths with gantry and terminal cranes that were still lacking at developing countries. However in 2016, seven ports are Chinese (including Hong Kong) within the top ten, following high economic growth and rapid port development since the 2000s. The other three ports are also Asian, like Singapore, Busan, and Dubai.

Despite their initial domination within Asia, Japanese ports, and especially Kobe, had been taken over by other East Asian ports, especially by Busan due to networks effects and the Hanshin Earthquake in January 1995 (Xu and Itoh, 2018). In a similar vein, and after playing a crucial role as a gateway and hub for mainland China due to its pre-1997 status as an independent city-state with Western trade practices, lost cargo in the last decade to Shenzhen, which is adjacent to Hong Kong. By contrast, Singapore maintained its port growth as the transit point between Pacific Ocean and Indian Ocean connecting Asia with Europe, and highly frequent feeder services with neighboring Southeast Asian countries. Yet, competitors started to emerged such as Tanjung Pelepas in Malaysia (2000), Cai-Mep Thi-Vai in Vietnam (1996), and Jakarta / New Priok in Indonesia (under construction) to provide alternative transit points and enhance their respective local economies.

\section{[Table 1]}

In this chapter, we discuss the changes of maritime and port logistics affected by containerization in the last 50 years. In section 2 , we show the impact of containerization on the

\footnotetext{
${ }^{1}$ Based on the ship size which can navigate on Panama Canal, the size which cannot navigate on the canal is defined as Post (Over) -Panamax.
} 
world economy and global maritime networks including supply chain. Section 3 discusses the function of container terminal enhancing maritime transport and connecting the land and sea transports, especially in this section about the constraint and challenges of port development for larger ships and about the port management and terminal operation. In section 4, we present operational logics of shipping lines and alliances while providing concrete empirical evidences on changing patterns of global container flows. As reference, next Chapter 2 discusses port hinterland which is the connection to port on the land side with shippers.

\section{Economic growth and container cargo movements}

The innovation of containerization in maritime trade cause a rapid expansion of global trade (see also Bernhofen et al., 2013). Figure 1 compares the evolution of different maritime trades in the last four decades (the handling level of 1990 is base-line). Most of goods shipped in containers being general cargo, or intermediate and finished goods, container traffic had expanded much quicker than general cargo, especially after 1998 (see also Figure 4). Indeed, a growing share of general cargo had become containerized in the last two decades. In addition, the impacts of global recession for maritime trade were much bigger on container than on general cargoes.

[Figure 1]

The relationship between maritime trade, especially containerization, and economic activities, Figure 2 shows the increasing rate changes of container handlings volumes (TEUs) and dry cargo (ton base) compared to Global Domestic Product (GDP) in the last four decades or so. Except for 1998 and 2009, the increasing rate of container handling volumes was higher than the ones of dry cargo and GDP. The average growth rate of container handling is about $9.6 \%$ as compared to $4.1 \%$ for dry cargo and $3.0 \%$ for GDP. On the other hand, the standard deviation of container handling growth rates is 5.8, compared with 5.0 and 1.3 for dry cargo and GDP, respectively. Several factors can explain such a result. First, handling items in containers are mainly high value added goods (i.e. consumption and intermediate goods), so that the demand of container transport is less stable than for general cargo and natural resources (i.e. bulks). Second, container handling is highly connected with economic circulation. For example, the correlation coefficients of the growth rates with GDP are 0.66 with container and 0.47 with dry cargo. Third, slowing trade, or increasing global GDP is higher than for global trade, as the Lehman shock is said to have finished in 2017 (CPB Netherlands Bureau for Economics Policy Analysis, 24 $4^{\text {th }}$ November, 2017). 
[Figure 2]

When observing the growth rates of container handling volumes and GDP by countries (see Appendix, Table A1), again, the growth rate of container handling has been higher than that of GDP. However, the current Chinese growth rates of container handling remain rather moderate, while the one of Hong Kong had been negative in the last five years. The center of gravity of economic expansion had, indeed, shifted towards South Asia, like Indonesia and Vietnam (Itoh, 2012).

Figures 3 (a) and (b) show the relative scales of container handling volumes and value added (GDP) by regions/countries (see Appendix, Table A2). Until the mid-1990s, most of container traffic was handled in advanced economies and regions as mentioned above, until Chinese ports increased their share after 1995, and especially 2001 (entry of China in the World Trade Organization (WTO)). Nowadays, the total Chinese share including Hong Kong is more than $30 \%$, while European ports witnessed a decrease from 30\% in 1975 to $12 \%$ in 2015. Although Hong Kong had increased their global share until the middle of 1990s, their share was taken by the mainland Chinese ports by the container terminal developments, turning into a global financial and value-added center instead of a cargo handling hub (see Wang and Chen, 2010).

On the other hand, the relative shares of GDP have been changing more smoothly than for container handling. For example, although the Chinese economy including Hong Kong occupies about $12 \%$ in 2015 , the advanced economies, like NA, Europe (Germany, UK, and France) and Japan still take their position to some extent. This result is partly due to the fact that container handling volumes are sometimes inflated by official statistics because of large transshipment volumes, leading to double-counts of each container move.

[Figure 3]

Until the end of 1990s, the relative changes of economic activities (GDP) and cargo movements (containers) had maintained relatively tight linkages. In Figure 4, the correlation coefficients between the relative shares of GDP and container handling on countries (see Appendix, Tables A2) had been increasing until 1999. The decrease after 2000, including China's entry in the WTO and the global financial crisis effects, can be explained by the rapid progress of supply chain development in emerging economies (i.e. BRICS countries), especially in Asia, and a growing imbalanced international horizontal division of production (see Table 2).

[Figure 4] 
Tables 2 (a) and (b) show the inter- and intra-regional container movements in 1998 and 2016. As discussed above, the distribution of container and economic activities had been tightly connected until 1999. However, they are less connected in the 2000s. The center of gravity of container movements have been shifting to intra-regional activities in Asia in a context of increased regional integration, thereby concentrating more than $25 \%$ of global container movements. Nowadays, the impact of economic growth on container movements is amplified and imbalanced on routes, or highly weighted inside Asia. Containerization had increased the speed of economic growth at emerging economies and expanded the imbalance of cargo movements on routes and regions throughout the world.

[Table 2]

\section{Port development and terminal operations}

\subsection{Terminal development and new ports opening}

The first ship in 1956 by McLean delivered 58 boxes. Containerships expanded through economies of scale (see Table 3) as underlined by Cullinane and Khanna (2000). For instance, although ship capacity was less than one thousand in the 1960s, nowadays the world's largest containership "MOL Triumph" of the shipping line MOL built in 2017 reaches more than 20 thousand Twenty-foot Equivalent Units (20,170 TEUs), 400m length, and 59m width. As a consequence, such "mega-ships" require high-standard container terminals in terms of both berth length and depth (see Ducruet and Berli, 2018 for an empirical analysis of the global distribution of mega-ship traffic). These facilities affect port operational efficiencies (Tongzon, 2001; Itoh 2002) and leads to a debate on whether ports and nation-states should follow such a trend. Previously already, so-called "Post-Panamax II" ships carrying about 8,000 TEUs needed the container berth with 16-18 meters water depth and 18,000 TEUs capacity on the terminal (ULCS).

[Table 3]

Larger-size container ship imposes the expansion of container terminals. Except the ports of Marseilles and Barcelona in Europe, Los Angeles and Long Beach in NA, numerous ports are located upstream rivers and estuaries as a reflection of their historical background of port development, so that their expansion faces important limitations, with Antwerp and Hamburg as exceptional cases (Notteboom, 2016). This explains why larger ships increasingly call at deepwater ports, the exemplary case being London, mainly served by Felixstowe (operated by Hong 
Kong- based Hutchinson Whampoa), 250 kilometers away, although recently the global operator Dubai Ports World (DPW) developed the new London Gateway container terminal with the slogan "ship closer, save money". Rotterdam is a special case as it has been relocating its container terminals by sea reclamation through the Maasvlakte projects. Most of nowadays ports and container terminals have to invest in mega gantry cranes, or longer arm of crane, for lifting on and off the containers inside a width ship.

In East Asia, the ports of Shanghai and Busan also had constructed new container terminals through sea reclamation (i.e. Yangshan deep-water port in 2005, Busan New port in 2006). Elsewhere, Laem Chabang in Thailand (1991) and Cai-Mep Thi-Vai in Vietnam (1996) were newly constructed for containerization away from their old river ports (i.e. Bangkok and Ho Chi Minh, respectively). Lastly, the new port of Tanjung Pelepas in Malaysia (2000) was constructed for competing with Singapore (see Table 1). At its opening, APM Terminals, the main terminal operator of Maersk, shifted from Singapore to Tanjung Pelepas, it's the direct effect of decreasing Singapore's traffic by $30 \%$, for the sake of competition but also as a way to bargain port costs. Following Maersk, Evergreen also shifted their hub-port to Tanjung Pelepas. Although Maersk returned to Singapore less than a year later, Tanjung Pelepas has been increasing its container throughput in the last years.

\subsection{Port management and terminal operations}

Although the port logistics industry before containerization was more labor-intensive, container terminal activity remains a highly capital-intensive industry. As discussed above, larger-size container ships needs high-standard container terminals, handling facilities and equipments. Most of the global major container terminals are operated by (public and private) port operating companies and terminal operators instead of (central and local governmental) port managers (Figure 5), because the operation and management of container terminal needs massive investments and management technology, and has been making profits with the growth of container transport.

\section{[Figure 5]}

In general, port management is classified amongst the following four types; 1) central government management, 2) local government management, 3) public enterprise management, and 4) private company management. Types 3) and 4) are consolidated as port operating company as seen in Figure 5. In Type 1), central government management, due to the lack of reliability, agility, and efficient management, is not so much common, except in the case of Hong Kong before the handover to China (1997). However, central governments are concerned by the 
development of basic facilities on the sea and port side (waterways, breakwater, and infrastructure). Most ports are managed by Type 2) local governments (European major ports, the ports of Los Angeles, Long Beach, Miami, and Everglade, Japanese major ports) and Type 3) public firms because of the large local economic impacts of port activities. Type 3) public businesses are divided into some cases based on the independence of budget and decision making on port business and planning. For example, local governments established public firms (i.e. government-affiliated firms, such as Korea Container Terminal Authority and Singapore Port Authority - PSA, before privatization), which manage port operation. They often establish public corporations under specific activity framework at the region level (e.g. Kaohsiung, Keelung, Seattle, and Tacoma). Lastly, a firm, which has public elements and constraints, is established under (general) company law. As the example of Type 4) private company, the ports of United Kingdom (UK) and New Zealand are managed by fully private companies (Doi, 2003).

Port operating types are thus classified into four types based on the construction, ownership, and operation of infra-and super-structure between port manager and port (terminal) operator. In addition, leased home is divided into two types for port facilities (infra-structure and super-structure) (Table 4). About term-leased land, port operator constructs not only super structure (gantry and yard cranes, container yard, shed, and warehouse) but also infra-structure (berthing facilities). For example, most Western ports (i.e. Europe and NA) are leased home without super-structure type. However, the port of Hong Kong is term-leased land without noprofit infrastructure type (or, waterway and breakwater). The terminal operator at Hong Kong pays concession money of terminal development to Hong Kong government, and develops new terminal including landfill, terminal facilities' construction and their equipment procurements. Although new terminal developed by the operator belongs to Hong Kong government, the operator borrows terminals and operates the terminal. The port of Singapore was also managed by the central government. However, all its terminals were transferred to PSA by privatization in 1997. UK ports were also privatized in the second half of the 1980s (Kurihara, 2014).

[Table 4]

Terminal operators are classified into two types; 1) global stevedores' terminal operator and 2) global carrier's terminal operators (Table 5). The first type (1) is a pre-play company focused on port service business. Most of stevedores mainly operate at their home-base and neighboring areas focusing on competitive and efficient operations. For example, although HPH has 52 terminals in 26 countries in 2017, they have 9 terminals in China and Hong Kong. The second type (2) is divided into two sub-types. On the one hand, terminal operation is focused as profit center inside their group company working for other shipping lines. On the other hand, the 
second case is focused as cost center for more efficient operations inside their group company's shipping network. In the past, major carriers had been making their global terminal operation supporting maritime business of their mother companies (or, cost center). However, under difficult situations in a sensitive shipping market (cf. Figure 2), port service business' profit has become more stable than maritime business. Therefore, some shipping lines changed their terminal service not only for own shipping lines but also other (competitive) shipping lines and group at their own / dedicated terminals for getting lower handling charges. Nowadays, about $80 \%$ of total container throughput at terminals are handled by global operators, and this share has been increasing $(78.8 \%$ in 2015 , cf. Table 6$)$.

\section{[Table 5]}

[Table 6]

\section{Global maritime container shipping}

It is now well-known that horizontal integration pushed shipping lines to deploy global networks by the principle of merger and acquisition, such as Maersk (Frémont, 2007) and CMA-CGM (Frémont, 2015), although there are variants in the way this process had taken place among companies and among regions (Slack and Frémont, 2009). Global maritime container flows are currently transported by a handful of large companies, often through alliances, with a growing concentration that accelerated after the 2008 Financial Crisis (see Table 7), which led to important turmoil in the shipping industry until the bankruptcy of Hanjin Shipping in 2017. Other companies adopted the strategy of slow steaming, defined by decreasing travel speed and increased vessel size, to increase economies of scale, save fuel and money, and at the same time, send to scrap their older or smaller vessels. Certain shipping, to avoid financial losses, even reincorporated favorable sailing winds in their route operations to save even more fuel and money. In the meantime, other costs are trying to be levied through China's efforts to build a round-theworld Maritime Silk Road (Wang et al., 2018), trying to bypass Panama Canal costs through the project of a new Nicaragua Canal, and to bypass the Suez Canal through a railway land bridge through Israel, as well as a through Myanmar to avoid the Malacca Straits. The pattern of global shipping is thus still changing very fast and a lot of research remains to be done to foresee what will be routes of the future. For the rest, the Arctic passage, should it be Canadian or Russian, is still not yet a reality and is a very minor priority for container shipping given all the geopolitical, technical, and financial issues not resolved yet. 
[Table 7]

A glimpse of what the current (or recent) world pattern of maritime container flows is proposed in Figure 6, where we can see the major routes and trunk lines' distribution across the globe. Regional integration in East Asia and the major link between Europe and Asia are responsible for the concentration in these parts of the world, notwithstanding an important share of Trans-Pacific trade, bur which is more imbalanced due to the large proportion of boxes returning empty from NA to Asia (see also Table 2).

[Figure 6]

The aforementioned changes and dynamics are examined in this section in two ways. First, we recall the main operational aspects of shipping lines to give a better understanding on how they design their various liner shipping services. Second, we provide some empirical evidence on how these economic and operational aspects have affected the distribution of global shipping flows in the last decade.

\subsection{Operational aspects of liner shipping services}

Apparently very complex, the way shipping lines organize their services is based on numerous factors but a few key principles, as seen in Figure 7. All is a matter of business profitability, but with the exception, compared with other businesses, of geographic aspects that shipping lines cannot avoid. They thus analyze the route along which ships should be deployed (fleet), and in the meantime, zoom on the route to select the best ports of call according to multiple criteria that are so much researched in the literature. Why this port and not another is not a straightforward question, which has to do with efficiency, performance, technical quality and capacity, handling costs, and presence of specific arrangement with terminal operators, finally the proximity or not to the end markets (Tiwari et al., 2003; Tongzon, 2009). Shipping lines are often said to be "footloose" in terms of port selection because they keep a certain margin in the case of disruption in transport chains (Achurra-Gonzalez et al., 2017), due to many causes (dockers'strikes, natural disasters, etc.). Then come the choice of service shipping lines offer to their customers (mainly, shippers) to satisfy their needs. Volatility, freight rate fluctuation, and seasonality also come into play.

[Figure 7] 
The main configuration is based on "bundling" as a key driver of container service design. This can take place at two levels: individual liner service or bundling by combining/linking two or more liner services. The first aims to "collect container cargo by calling at various ports along the route instead of focusing on an end-to-end service" (Ducruet and Notteboom, 2012). This service is a set of several roundtrips of several vessels having in common calling patterns (i.e. order of port calls) and time intervals (i.e. frequency) between consecutive port calls. The overlap of all these roundtrips provide an optimal calling frequency. It is important to note that bundling can be symmetric or asymmetric; in the latter case, different ports of calls are used on the way back. In general, carriers select about five ports of call per loop, keeping in mind that increases in vessel size may have even decreased the number of ports of call. Two extreme forms of line bundling are round-the-world services and pendulum services.

Another option is to bundle container lines by combining two or more liner services as follows: hub-and-spoke network (hub/feeder), interlining, and relay. On their side, governments and port authorities invested heavily in the development of specific redistribution nodes to make it happen, called "intermediate hubs" (Rodrigue and Notteboom, 2010). Such hubs should provide good nautical accessibility, proximity to main shipping lanes and ownership, in whole or in part, by carriers or multinational terminal operators, most of those being located along the East-West circumterrestrial trunk line, "in-between" main producer or consumer markets. Their pivotal role complements the one of so-called "gateway ports" within those markets to access final consumers through hinterland services. Container carriers use both gateways and hubs to design their services in the most efficient way possible, but it was demonstrated that the same node is often "dedicated" to one main shipping line (Frémont and Soppé, 2009), just like terminal operators, through concession agreements (Notteboom et al., 2012). Another strategy of shipping lines is to focus on a preferential corridor development by investing gateways and inland ports (Franc and Van der Horst, 2010), often through vertical integration, especially in countries where the transport sector is more liberalized (Ducruet and Van der Horst, 2009).

\subsection{The evolution of flow patterns}

One simple and classic way to investigate how have container port traffic patterns evolved under the aforementioned circumstances is to look at two famous concentration indices, namely Gini coefficient and Herfindahl-Hirschman Index (HHI) (Figure 8). The latter 
index exhibits a clear tendency towards a de-concentration as many more ports are constructed and adopt the "container revolution" through successive diffusion waves across the world (Guerrero and Rodrigue, 2014). Thus, the bulk of global container port traffic is less and less concentrated in the top of the world hierarchy overtime. In opposition, but without being contradictory to the previous observation, there is a tendency (cf. Gini coefficient) for this traffic to be increasingly concentrated across space, despite a less clear-cut trend and several fluctuations. For example, although the concentration (Gini coefficient) of port traffic in Asia had been stable between 1985 and 2005, the gaps inside Southeast, South and West Asia, or containerized backward regions, had been expanding (Itoh, 2012). We cannot observe a paramount concentration but this is the trend until the early 2000 s as containerization has been highly selective and concentrated around large hubs and gateways, until a process of de-concentration occurred, already exemplified by the pioneering work of Hayuth (1981) on the matter. The global shift of manufacturing from the Western to the Asian world is also responsible for such a mixed evidence, including the "China effect", especially since its integration in the WTO in 2001.

\section{[Figure 8]}

Another but complementary way to understand the evolution of the global pattern of container flows is to apply one of the simplest graph-theoretical algorithms to the unweighted inter-port matrix of vessel flows (Figure 9), namely the Gamma index, often coined "density" in the network-analytical literature, i.e. the proportion of observed links (or "edges") in the maximum possible number of links in the network (see Ducruet and Lugo, 2013 for a review of transportation network measures). The clear decline proves that at least until the late 1990s and early 2000s, global container flows went through a process of rationalization and simplification, i.e. a lesser number of linkages compared with the number of ports, resulting in a star-like configuration, or hub-and-spokes, as a consequence of the aforementioned strategies of shipping lines when designing their networks and selecting large hubs. Despite a revival and re-densification of the network afterwards especially just after the global financial crisis, the latter shifted again towards centralization so that the last value of 2016 is the lowest of the time-series. This means a lot about global trade and connectivity in terms of vulnerability vs. robustness, as the routes of the past have been replaced by ever-more efficient and optimal routes centered around large hubs and gateways, but at the expense of smaller, medium-size ports that cannot access the rest of the network without passing through this recently installed 
redistribution platforms.

[Figure 9]

\section{Conclusion}

This chapter recalled and demonstrated deep changes in the way maritime transport had been reorganized with the ongoing advent of containerization in the past decades up to nowadays. This multifaceted approach to containerization is not so common as often, specific aspects are well covered and analyzed by scholars and professionals but without offering an all-encompassing view. Reviewing the complex and changing relationships between containerization (technological change) and economic development, port and shipping line operations, and related impacts on former ways of doing things is necessary before widening the approach to other segments of the global value and supply chain, such as hinterlands and shipping networks, as seen in the following chapters. We wish this book to become a useful if not a key reference to scholars, students, but also experts and practitioners for a better understanding of past, current, and future transformations of transport and logistics systems serving our world as a whole.

\section{References}

Achurra-Gonzalez P., Angeloudis P., Zavitsas K., Niknejad A., Graham D.J. (2017) Attackerdefender modelling of vulnerability in maritime logistics corridors. In: Ducruet (Ed.), Advances in Shipping Data Analysis and Modeling. Tracking and Mapping Maritime Flows in the Age of Big Data. Routledge Studies in Transport Analysis, Routledge: London \& New York, pp. 297-315.

Bernhofen D.M., El-Sahli Z., Kneller R. (2013) Estimating the effects of the container revolution on world trade. Lund University Working Paper 2013:4, Department of Economics, School of Economics and Management.

Cullinane K.P.B., Khanna M. (2000) Economies of scale in large containerships: optimal size and geographical implications. Journal of Transport Geography, 8(3): 181-195.

Doi M (Ed.) (2003) Economics of Ports and Regions, Tokyo, Taga-Shuppan. (in Japanese)

Ducruet C., Berli J. (2018) Mapping the globe: the patterns of mega-ships. Port Technology International, 77: 94-96.

Ducruet C., Berli J., Bunel M. (2018) Geography vs. topology in the evolution of the global container shipping network (1977-2016). In: Wilmsmeier G., Monios J. (Eds.), Geographies of Maritime Transport, Edward Elgar Publishing (forthcoming).

Ducruet C., Lugo I. (2013) Structure and dynamics of transportation networks: Models, concepts, 
and applications. In: Rodrigue J.P., Notteboom T.E., Shaw J. (Eds.), The SAGE Handbook of Transport Studies, SAGE Publications, pp. 347-364.

Ducruet C., Notteboom T.E. (2012) Developing liner service networks in container shipping. In: Song, D.W., Panayides, P. (Eds.), Maritime Logistics: A Complete Guide to Effective Shipping and Port Management, Kogan Page, pp. 77-100.

Ducruet C., Van der Horst M.R. (2009) Transport integration at European ports: Measuring the role and position of intermediaries. European Journal of Transport and Infrastructure Research, 9(2): 121-142.

Franc P., Van der Horst M.R. (2010) Analyzing hinterland service integration by shipping lines and terminal operators in the Hamburg-Le Havre range. Journal of Transport Geography, 18(4): 557-566.

Frémont A. (2007) Global maritime networks: The case of Maersk. Journal of Transport Geography, 15(6): 431-442.

Frémont A. (2015) A geo-history of maritime networks since 1945. The case of the Compagnie Générale Transatlantique's transformation into CMA-CGM. In: Ducruet C. (Ed.), Maritime Networks: Spatial Structures and Time Dynamics, Routledge Studies in Transport Analysis, London and New York, pp. 37-49.

Frémont A., Soppé M. (2007) Northern European Range: Shipping line concentration and port hierarchy. In: Wang J.J., Olivier D., Notteboom T.E., Slack B. (Eds.), Ports, Cities, and Global Supply Chains. Aldershot: Ashgate, pp. 105-120.

Guerrero D., Rodrigue J.P. (2014) The waves of containerization: shifts in global maritime transportation. Journal of Transport Geography, 35: 151-164.

Hayuth Y. (1981) Containerization and the load center concept. Economic Geography, 57(2): 160176.

Hoshino H. (1995) The impacts of Containerization to International Logistics. The Containerization, 272. (in Japanese)

Itoh H. (2002) Efficiency changes at major container ports in Japan: a window application of Data Envelopment Analysis. Review of Urban \& Regional Development Studies, 14(2): 133-152.

Itoh H. (2012) Structural Changes in Port Cargo Flow Distribution in Asian Container Port Systems. the proceeding at the International Association of Maritime Economist (IAME) Annual Conference, 6-8 September, 2012, Taipei, Taiwan.

Kurihara Y. (2014) The global trend of port service industry. Mitsui \& Co. Global Strategic Studies Institute. (in Japanese)

Morel J.C., Ducruet C. (2015) Interview - The man who brought containerisation to Europe. Portus Online, 29: http://portusonline.org/fr/interview-the-man-who-broughtcontainerisation-to-europe/ 
Levinson M. (2006) The Box: How the Shipping Container Made the World Smaller and the World Economy Bigger. Princeton University Press.

Mori T. (2018) Introduction to Modern Logistics. $3^{\text {rd }}$ Edition, Tokyo, Dobunkan Publisher. (in Japanese)

Notteboom T.E. (2016) The adaptive capacity of container ports in an era of mega vessels: The case of upstream seaports Antwerp and Hamburg. Journal of Transport Geography, 54: 295309.

Notteboom T.E., Pallis A.A., Farrell S. (2012) Guest editorial: Terminal concessions in seaports revisited. Maritime Policy and Management, 39(1): 1-5.

Ohmae K. (1985) Triad Power: The Coming Shape of Global Competition. Paris: Flammarion (translation in French).

Rodrigue J.P. (2017) The Geography of Transport Systems. $4^{\text {th }}$ Edition, New York, Routledge.

Rodrigue J.P., Notteboom T.E. (2010) Foreland-based regionalization: Integrating intermediate hubs with port hinterlands. Research in Transportation Economics, 27(1): 19-29.

Slack B., Frémont A. (2009) Fifty years of organisational change in container shipping: regional shift and the role of family firms. Geojournal, 74(1): 23-34.

Tiwari P., Itoh H, Doi M. (2003) Shippers' port and carrier selection behaviour in China: a discrete choice analysis. Maritime Economics \& Logistics, 5(1): 23-39.

Tongzon J. (2001) Efficiency measurement of selected Australian and other international ports using data envelopment analysis. Transportation Research Part A, 35: 107-122.

Tongzon J. (2009) Port choice and freight forwarders. Transportation Research Part E, 45: 186195.

Wang J.J., Chen M.C. (2010) From a hub port city to a global supply chain management center: A case study of Hong Kong. Journal of Transport Geography, 18(1): 104-115.

Wang L., Zhu Y., Ducruet C., Bunel M., Lau Y.Y. (2018) From hierarchy to networking: The evolution of the 21 st century Maritime Silk Road' container shipping system, Transport Reviews, 38(4) : 416-435.

Xu H., Itoh H. (2018) Density economies and transport geography: Evidence from the container shipping industry. Journal of Urban Economics, 105: 121-132. 
Table 1: The container handling ranking changes at ports (unit: thousand TEUs)

\begin{tabular}{|c|c|c|c|c|c|c|c|c|c|c|}
\hline & \multicolumn{2}{|l|}{1975} & \multicolumn{2}{|l|}{1980} & \multicolumn{2}{|l|}{1985} & \multicolumn{2}{|l|}{1990} & \multicolumn{2}{|l|}{1995} \\
\hline 1 & $\mathrm{NY} / \mathrm{NJ}$ & 1,730 & $\mathrm{NY} / \mathrm{NJ}$ & 1,947 & Rotterdam & 2,655 & Singapore & 5,220 & Hong Kong & 12,550 \\
\hline 2 & Rotterdam & 1,079 & Rotterdam & 1,901 & $\mathrm{NY} / \mathrm{NJ}$ & 2,367 & Hong Kong & 5,100 & Singapore & 11,846 \\
\hline 3 & Kobe & 905 & Hong Kong & 1,465 & Hong Kong & 2,289 & Rotterdam & 3,670 & Kaohsiung & 5,232 \\
\hline 4 & San Juan & 877 & Kobe & 1,456 & Kaohsiung & 1,901 & Kaohsiung & 3,490 & Rotterdam & 4,787 \\
\hline 5 & Hong Kong & 802 & Kaohsiung & 979 & Kobe & 1,857 & Kobe & 2,600 & Busan & 4,503 \\
\hline 6 & Oakland & 522 & Singapore & 917 & Singapore & 1,699 & Busan & 2,350 & Hambrug & 2,890 \\
\hline 7 & Seattle & 481 & San Juan & 852 & Yokohama & 1,327 & Los Angeles & 2,120 & Yokohama & 2,757 \\
\hline 8 & Baltimore & 421 & Long Beach & 825 & Antwerp & 1,243 & Hambrug & 1,970 & Los Angeles & 2,555 \\
\hline 9 & Bremen & 410 & Hambrug & 783 & Long Beach & 1,172 & $\mathrm{NY} / \mathrm{NJ}$ & 1,900 & Long Beach & 2,390 \\
\hline 10 & Long Beach & 391 & Oakland & 782 & Hambrug & 1,159 & Keelung & 1,810 & Antwerp & 2,329 \\
\hline 11 & Tokyo & 369 & Seattle & 782 & Keelung & 1,158 & Yokohama & 1,650 & $\mathrm{NY} / \mathrm{NJ}$ & 2,276 \\
\hline 12 & Melbourne & 365 & Antwerp & 724 & Busan & 1,115 & Long Beach & 1,600 & Tokyo & 2,177 \\
\hline 13 & Keelung & 246 & Yokohama & 722 & Los Angeles & 1,104 & Tokyo & 1,560 & Keelung & 2,170 \\
\hline 14 & Hambrug & 326 & Bremen & 703 & Tokyo & 1,004 & Antwerp & 1,550 & Dubai / Jebel Ali & 2,073 \\
\hline 15 & Antwerp & 297 & Keelung & 660 & Bremen & 986 & Felixstowe & 1,420 & Felixstowe & 1,898 \\
\hline 16 & Virginia & 292 & Busan & 634 & San Juan & 882 & San Juan & 1,380 & Manila & 1,668 \\
\hline 17 & Sydney & 262 & Los Angeles & 633 & Oakland & 856 & Seattle & 1,170 & San Juan & 1,593 \\
\hline 18 & London & 260 & Tokyo & 632 & Seattle & 845 & Bremen & 1,160 & Oakland & 1,550 \\
\hline 19 & Yokohama & 329 & Jeddah & 563 & Felixstowe & 726 & Oakland & 1,120 & Shanghai & 1,527 \\
\hline 20 & Le Havre & 232 & Baltimore & 523 & Baltimore & 706 & Manila & 1,039 & Bremen & 1,526 \\
\hline & \multicolumn{2}{|l|}{2000} & \multicolumn{2}{|l|}{2005} & \multicolumn{2}{|l|}{2010} & \multicolumn{2}{|l|}{2015} & \multicolumn{2}{|l|}{2016} \\
\hline 1 & Hong Kong & 18,100 & Singapore & 23,192 & Shanghai & 29,069 & Shanghai & 36,537 & Shanghai & 37,130 \\
\hline 2 & Singapore & 17,040 & Hong Kong & 22,427 & Singapore & 28,431 & Singapore & 30,922 & Singapore & 30,900 \\
\hline 3 & Busan & 7,540 & Shanghai & 18,084 & Hong Kong & 23,699 & Shenzhen & 24,204 & Shenzhen & 23,979 \\
\hline 4 & Kaohsiung & 7,426 & Shenzhen & 16,197 & Shenzhen & 22,510 & Ningbo & 20,620 & Ningbo & 21,560 \\
\hline 5 & Rotterdam & 6,280 & Busan & 11,843 & Busan & 14,194 & Hong Kong & 20,114 & Busan & 19,850 \\
\hline 6 & Shanghai & 5,613 & Kaohsiung & 9,471 & Ningbo & 13,144 & Busan & 19,469 & Hong Kong & 19,580 \\
\hline 7 & Los Angeles & 4,879 & Rotterdam & 9,300 & Guangzhou & 12,550 & Guangzhou & 17,625 & Guangzhou & 18,885 \\
\hline 8 & Long Beach & 4,601 & Hamburg & 8,088 & Qingdao / Tsingta & 12,012 & Qingdao / Tsingta & 17,510 & Qingdao / Tsingta & 18,000 \\
\hline 9 & Hambrug & 4,248 & Dubai / Jebel Ali & 7,619 & Dubai / Jebel Ali & 11,600 & Dubai / Jebel Ali & 15,592 & Dubai / Jebel Ali & 14,772 \\
\hline 10 & Antwerp & 4,082 & Los Angeles & 7,485 & Rotterdam & 11,146 & Tianjin & 14,100 & Tianjin & 14,500 \\
\hline 11 & Shenzhen & 3,994 & Long Beach & 6,710 & Tianjin & 10,080 & Rotterdam & 12,235 & Port Kelang & 13,183 \\
\hline 12 & Port Kelang & 3,207 & Antwerp & 6,482 & Kaohsiung & 9,181 & Port Kelang & 11,890 & Rotterdam & 12,385 \\
\hline 13 & Dubai / Jebel Ali & 3,059 & Qingdao / Tsingta & 6,307 & Port Kelang & 8,870 & Kaohsiung & 10,264 & Kaohsiung & 10,465 \\
\hline 14 & $\mathrm{NY} / \mathrm{NJ}$ & 3,050 & \begin{tabular}{|l|} 
Port Kelang \\
\end{tabular} & 5,716 & Antwerp & 8,468 & Antwerp & 9,654 & Antwerpen & 10,037 \\
\hline 15 & Tokyo & 2,899 & Ningbo & 5,208 & Hamburg & 7,900 & Dalian & 9,450 & Dalian & 9,614 \\
\hline 16 & Felixstowe & 2,853 & Tianjin & 4,801 & Tanjung Perapus & 6,530 & Xiamen & 9,183 & Xiamen & 9,414 \\
\hline 17 & Bremen & 2,712 & $\mathrm{NY} / \mathrm{NJ}$ & 4,793 & Long Beach & 6,263 & Tanjung Perapus & 9,120 & Hamburg & 8,910 \\
\hline 18 & Gioia Tauro & 2,653 & Guangzhou & 4,685 & Xiamen & 5,820 & Hamburg & 8,821 & Los Angeles & 8,857 \\
\hline 19 & Tanjung Priok / Ja & 2,476 & Tanjung Pelepas & 4,177 & $\mathrm{NY} / \mathrm{NJ}$ & 5,292 & Los Angeles & 8,160 & Tanjung Perapus & 8,029 \\
\hline 20 & Yokohama & 2,317 & Laem Chabang & 3,766 & Dalian & 5,242 & Long Beach & 7,192 & Laem Chabang & 7,227 \\
\hline
\end{tabular}

(Data) Containerization International Yearbook (-2009), and UNCTAD Stat (2010-2016). 
Table 2: World Container Movements (unit: thousand TEUs)

(a) 1998

\begin{tabular}{|c|c|c|c|}
\hline Origin/Destination & North America & Europe & East/Southeast Asia \\
\hline North America & - & $2,036(5.7 \%)$ & $3,338(9.4 \%)$ \\
\hline Europe & $1,509(4.2 \%)$ & - & $2,296(6.5 \%)$ \\
\hline East/Southeast Asia & $5,938(16.7 \%)$ & $4,246(12.0 \%)$ & $5,873(16.5 \%)$ \\
\hline
\end{tabular}

(Note) The estimated total container handling volumes are 35,528,000 TEUs. (Data) MOL Research Institute (1999).

(b) 2016

\begin{tabular}{|c|c|c|c|}
\hline Origin/Destination & North America & Europe & East/Southeast Asia \\
\hline North America & $482(0.3 \%)$ & $2,048(1.3 \%)$ & $7,252(4.7 \%)$ \\
\hline Europe & $3,913(2.6 \%)$ & $6,928(4.5 \%)$ & $7,022(4.6 \%)$ \\
\hline East/Southeast Asia & $16,708(10.9 \%)$ & $15,049(9.8 \%)$ & $39,214(25.6 \%)$ \\
\hline
\end{tabular}

(Note) The estimated total container handling volumes are 153,270,049 TEUs.

(Data) Japan Maritime Public Relations Center (2017). 
Table 5: The classification of global/international terminal operators

\begin{tabular}{|c|c|c|c|}
\hline & Classification & Management type & Ex. \\
\hline \multirow[b]{2}{*}{ Stevedores } & \multirow[b]{2}{*}{ Profit center } & Public company & PSA International, DP World, HHLA \\
\hline & & Private company & $\begin{array}{c}\text { Hatchison Port Handling (HPH), Eurogate, SSA } \\
\text { Marine, Dragados, Crup TCB, ICTSI }\end{array}$ \\
\hline \multirow{4}{*}{ Carriers } & \multirow[b]{2}{*}{ Cost center } & Public company & Terminal Investment Limited (TIL) \\
\hline & & Private company & $\begin{array}{l}\text { CMA/CGM, Evergreen, APL, Hanjin, K-line, } \\
\text { MISC, MOL, Yang Ming, Hyundai (HMM) }\end{array}$ \\
\hline & \multirow{2}{*}{ Profit center } & Public company & COSCO Pacific \\
\hline & & Private company & APMT, NYK \\
\hline
\end{tabular}

(Source) Mori (2018).

Table 6: Global/International terminal operators' throughput

\begin{tabular}{|r|l|r|r|}
\hline \multicolumn{1}{|c|}{ Operator } & Million TEU & Share (\%) \\
\hline 1 & China COSCO Shipping & 85.5 & $12.2 \%$ \\
\hline 2 & Hatchison Ports & 79.1 & $11.3 \%$ \\
\hline 3 & APM Terminals & 71.4 & $10.2 \%$ \\
\hline 4 & PSA International & 67.3 & $9.6 \%$ \\
\hline 5 & DP World & 62.4 & $8.9 \%$ \\
\hline 6 & Terminal Investment Limited (TIL) & 37.7 & $5.4 \%$ \\
\hline 7 & China Merchants Port Holdings & 28.5 & $4.1 \%$ \\
\hline 8 & CMA CGM & 16.6 & $2.4 \%$ \\
\hline 9 & Hanjin & 14.0 & $2.0 \%$ \\
\hline 10 & Eurogate & 11.9 & $1.7 \%$ \\
\hline 11 & SSA Marine / Carrix & 10.6 & $1.5 \%$ \\
\hline 12 & NYK & 9.6 & $1.4 \%$ \\
\hline 13 & Evergeen & 9.4 & $1.3 \%$ \\
\hline 14 & ICTSI & 8.7 & $1.2 \%$ \\
\hline 15 & OOCL & 6.7 & $1.0 \%$ \\
\hline 16 & China Shipping Terminal Development & 6.4 & $0.9 \%$ \\
\hline 17 & MOL & 5.9 & $0.8 \%$ \\
\hline 18 & Yildirim / Yilport & 5.6 & $0.8 \%$ \\
\hline 19 & Yang Ming & 4.4 & $0.6 \%$ \\
\hline 20 & Bollore & 4.3 & $0.6 \%$ \\
\hline Global/International Operators Total & 555.1 & $79.4 \%$ \\
\hline
\end{tabular}

(Data) Drewry (2017), Global Container Terminal Operators: Annual Review and Forecast. 
Table 7: The four major alliances on the east-west trades in 2015

Source: Frémont (2015)

\begin{tabular}{|c|c|c|c|}
\hline Alliance & Carriers & Country & $\begin{array}{c}\text { Market share }(\%) \text { on } \\
\text { the Asia-North } \\
\text { Europe trade }\end{array}$ \\
\hline \multirow{6}{*}{ G6 } & American President Line & Singapore & \multirow{6}{*}{24} \\
\hline & Hapag Lloyd & Germany & \\
\hline & Hyundai Merchant Marine & South Korea & \\
\hline & Mtsui OSK Line & Japan & \\
\hline & NYK Line & Japan & \\
\hline & $\begin{array}{c}\text { Orient Overseas Container } \\
\text { Line }\end{array}$ & Hong Kong & \\
\hline \multirow{5}{*}{ CKYHE } & $\mathrm{COSCO}$ & China & \multirow{5}{*}{24} \\
\hline & K Line & Japan & \\
\hline & Yang Ming & Taiwan & \\
\hline & Hanjin Shipping & South Korea & \\
\hline & Evergreen & Taiwan & \\
\hline \multirow{2}{*}{$2 \mathrm{M}$} & Maersk & Danemark & \multirow{2}{*}{31} \\
\hline & $\mathrm{MSC}$ & Switzerland & \\
\hline \multirow{3}{*}{$\begin{array}{l}\text { Ocean } \\
\text { Three }\end{array}$} & CMA-CGM & France & \multirow{3}{*}{21} \\
\hline & China shipping (CSCL) & China & \\
\hline & UASC & Qatar & \\
\hline
\end{tabular}


Figure 1: The relative expanding speeds of maritime trade

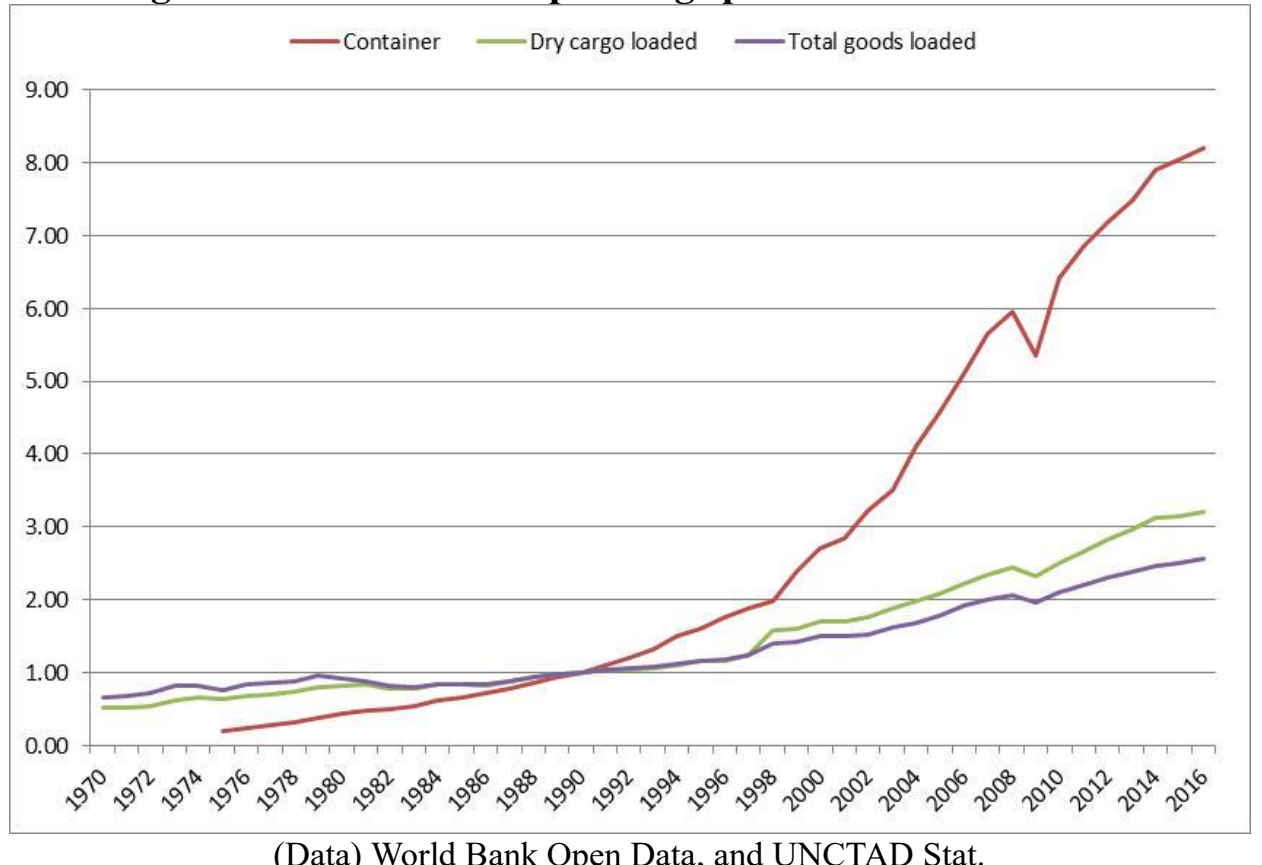

(Data) World Bank Open Data, and UNCTAD Stat. 
Figure 2: The increasing rate changes of container, dry cargo, and GDP

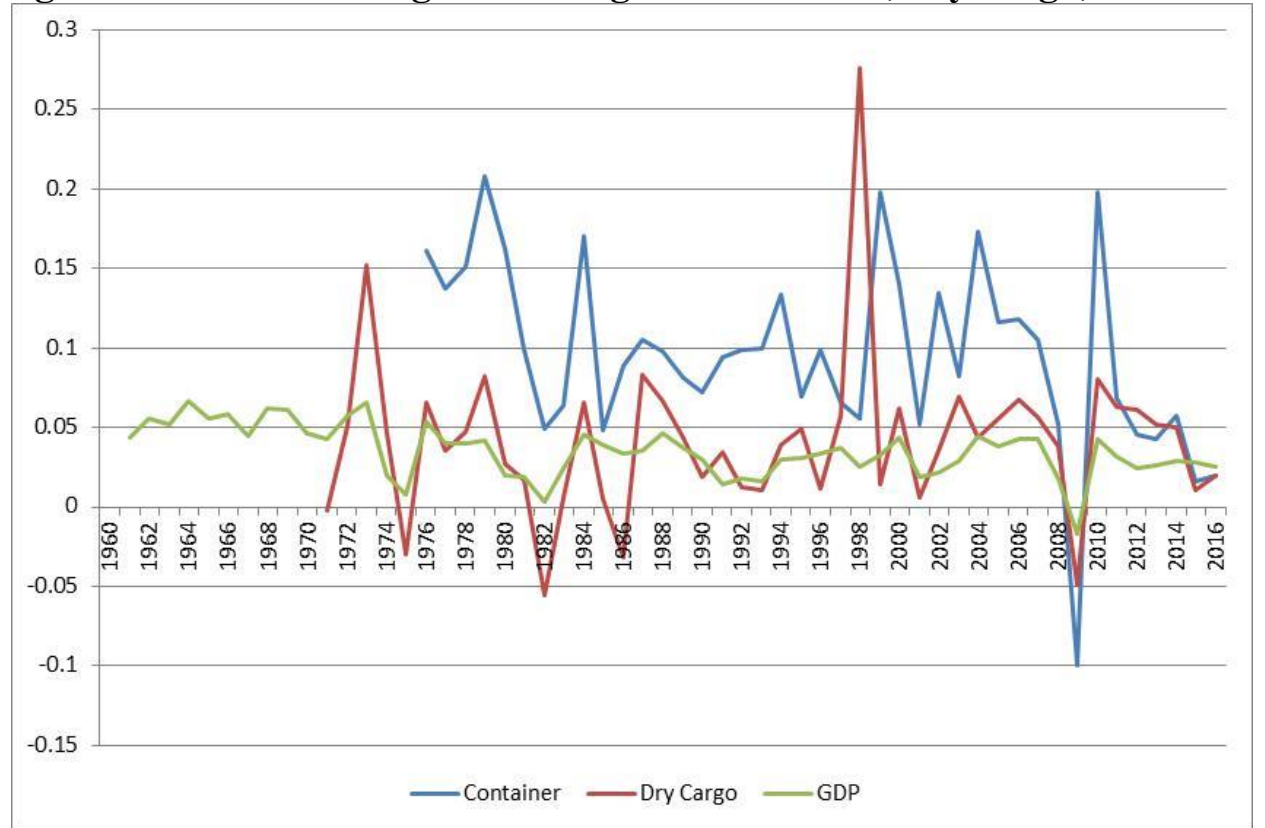

(Data) World Bank Open Data, and UNCTAD Stat. 
Figure 3: The shares for global total by countries/regions (a) Container handling volumes

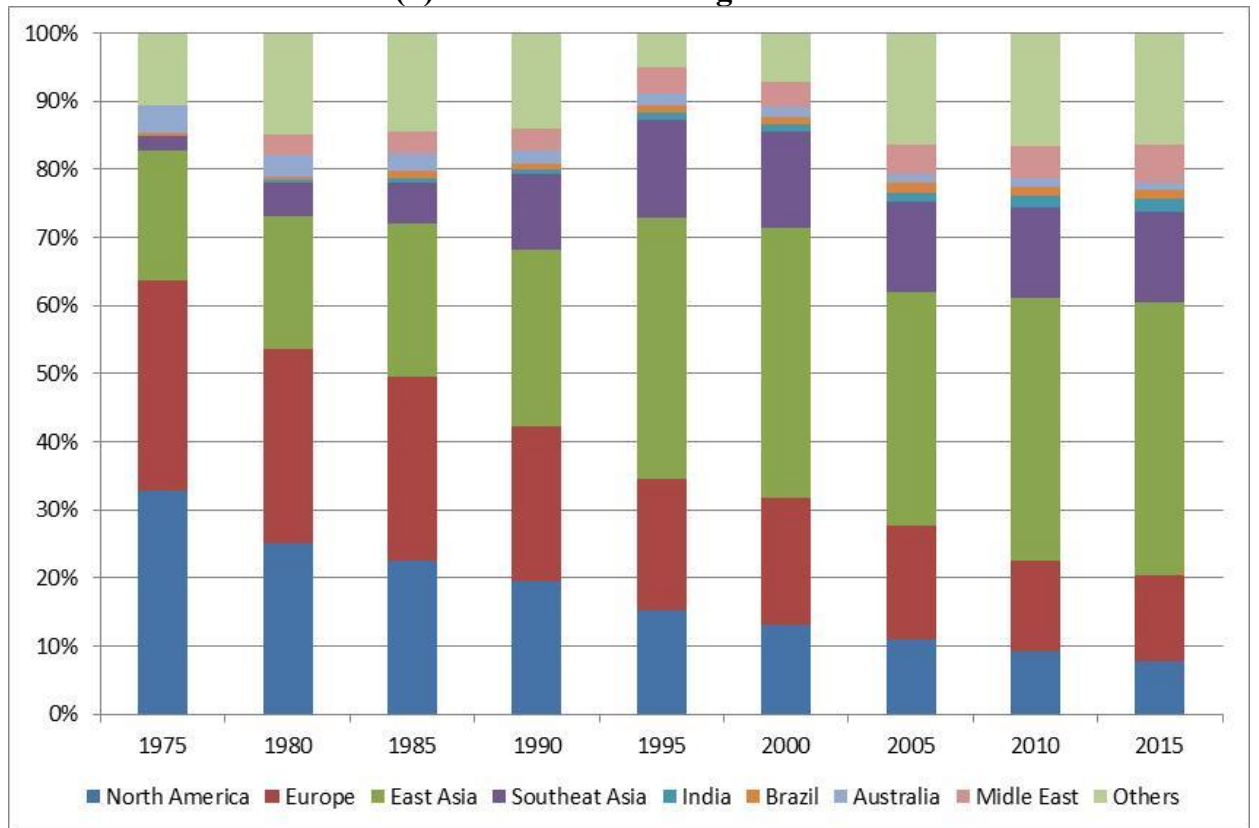

(Data) Based on the data from Table A2 (a).

(b) Gross Domestics Products (GDP)

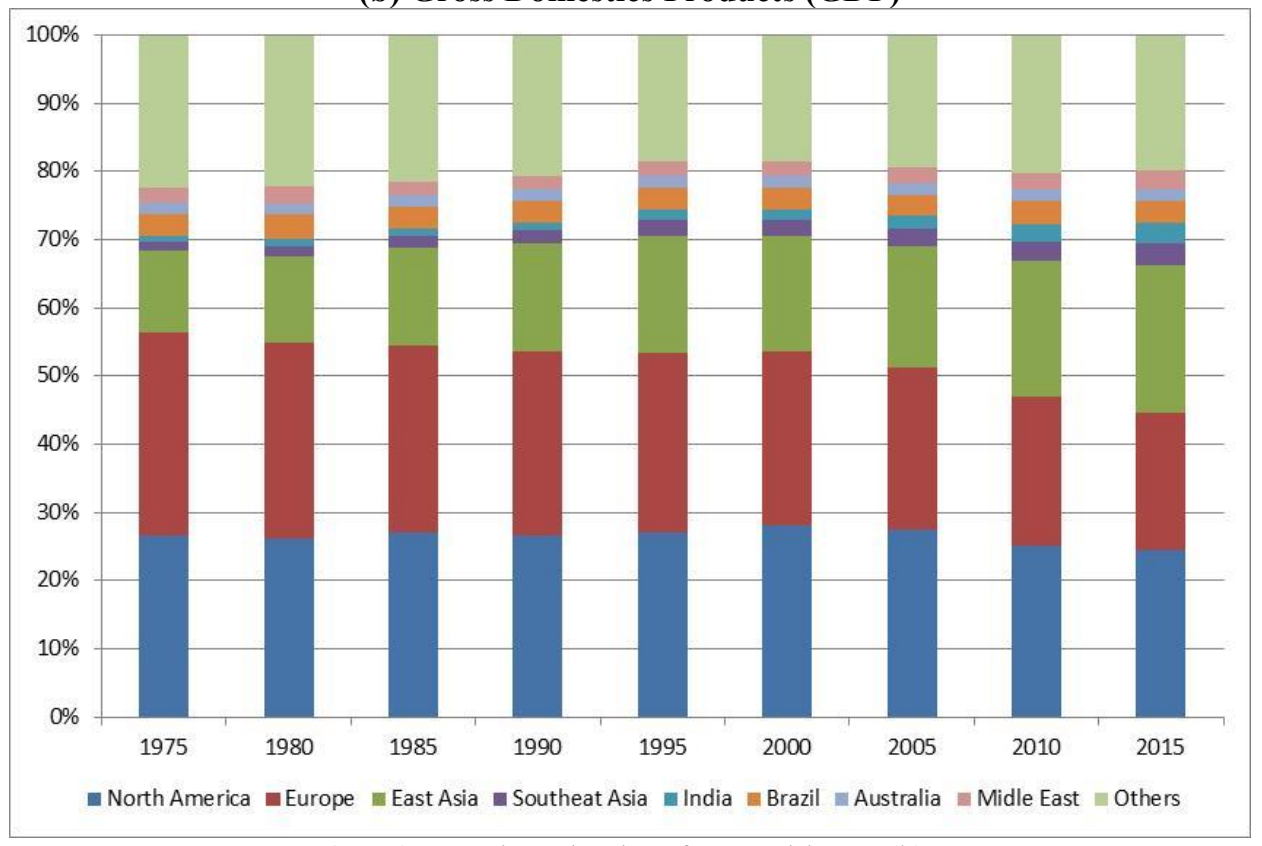

(Data) Based on the data from Table A2 (b). 
Figure 4: The correlation coefficients between GDP and container shares

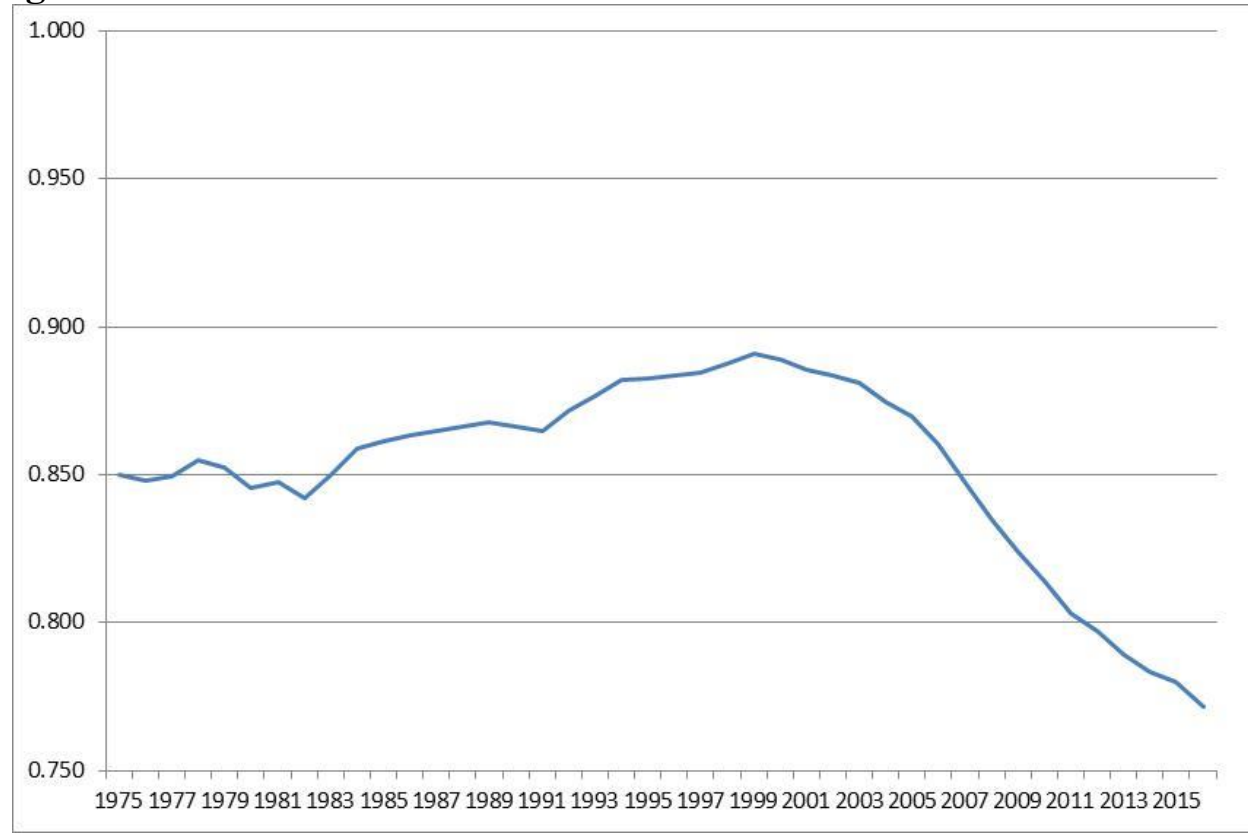

(Note) This figure is based on the data sets on Tables A1 (a) and (b). 
Figure 5: Container port management system

Use rights
Terminal Operator
Fees for facilities and operation
Port transport service provider


Figure 6: Global maritime container flows in 2016

Source: Ducruet et al. (2018)

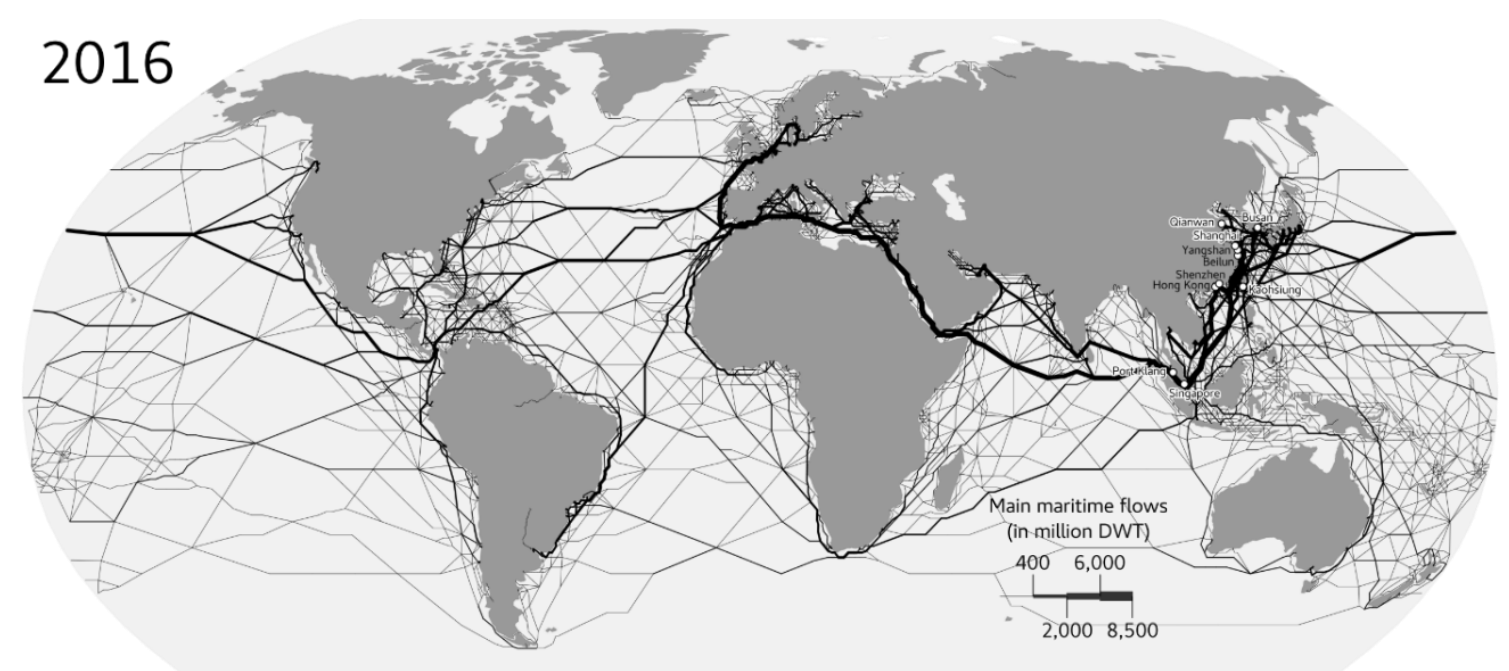


Figure 7: The process of liner service design

Source: Ducruet and Notteboom (2012)

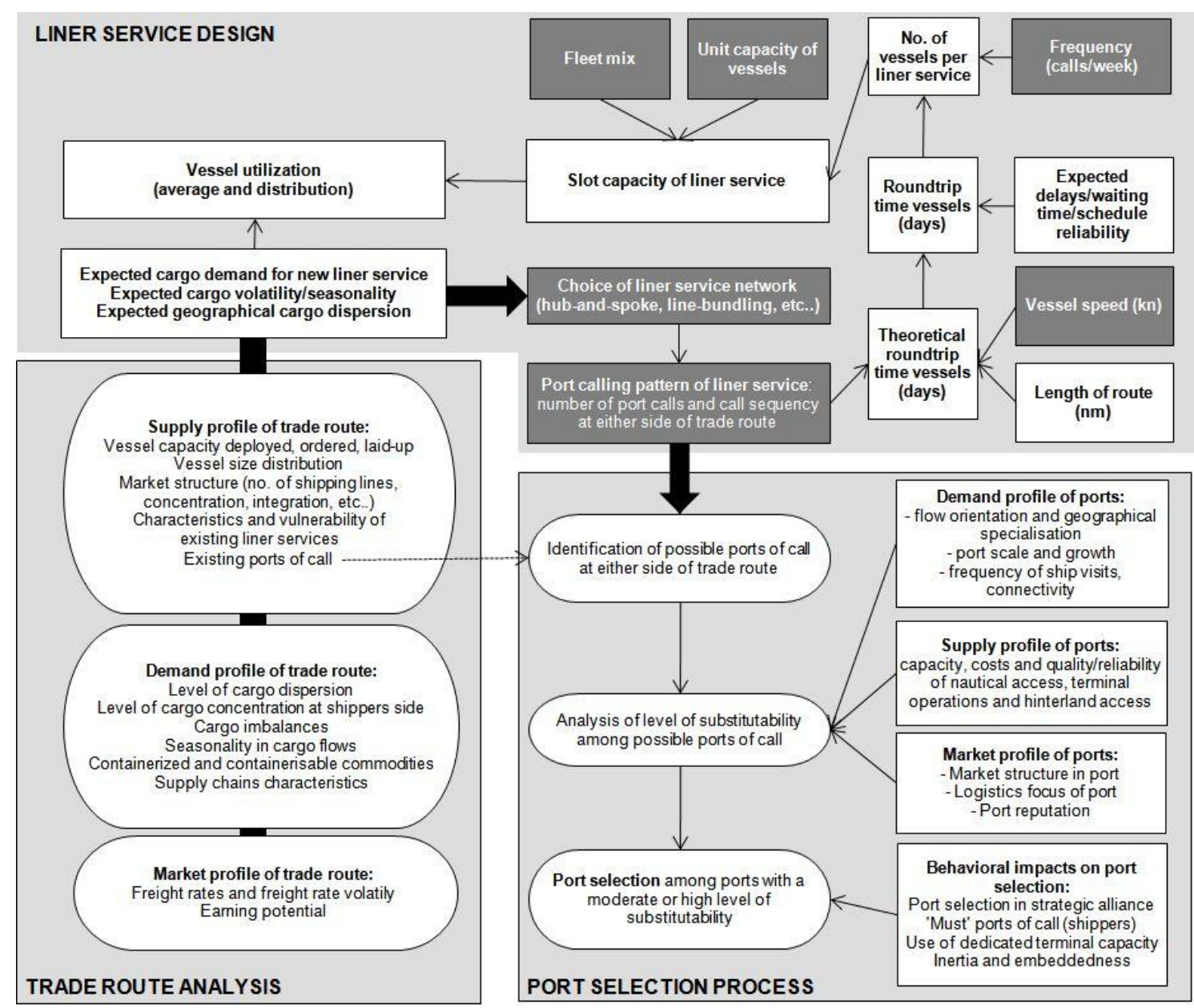


Figure 8: Global container port traffic concentration, 1977-2016

Source: own elaboration based on Lloyd's List Intelligence data

N.B. calculations realized using Wessa software, https://www.wessa.net

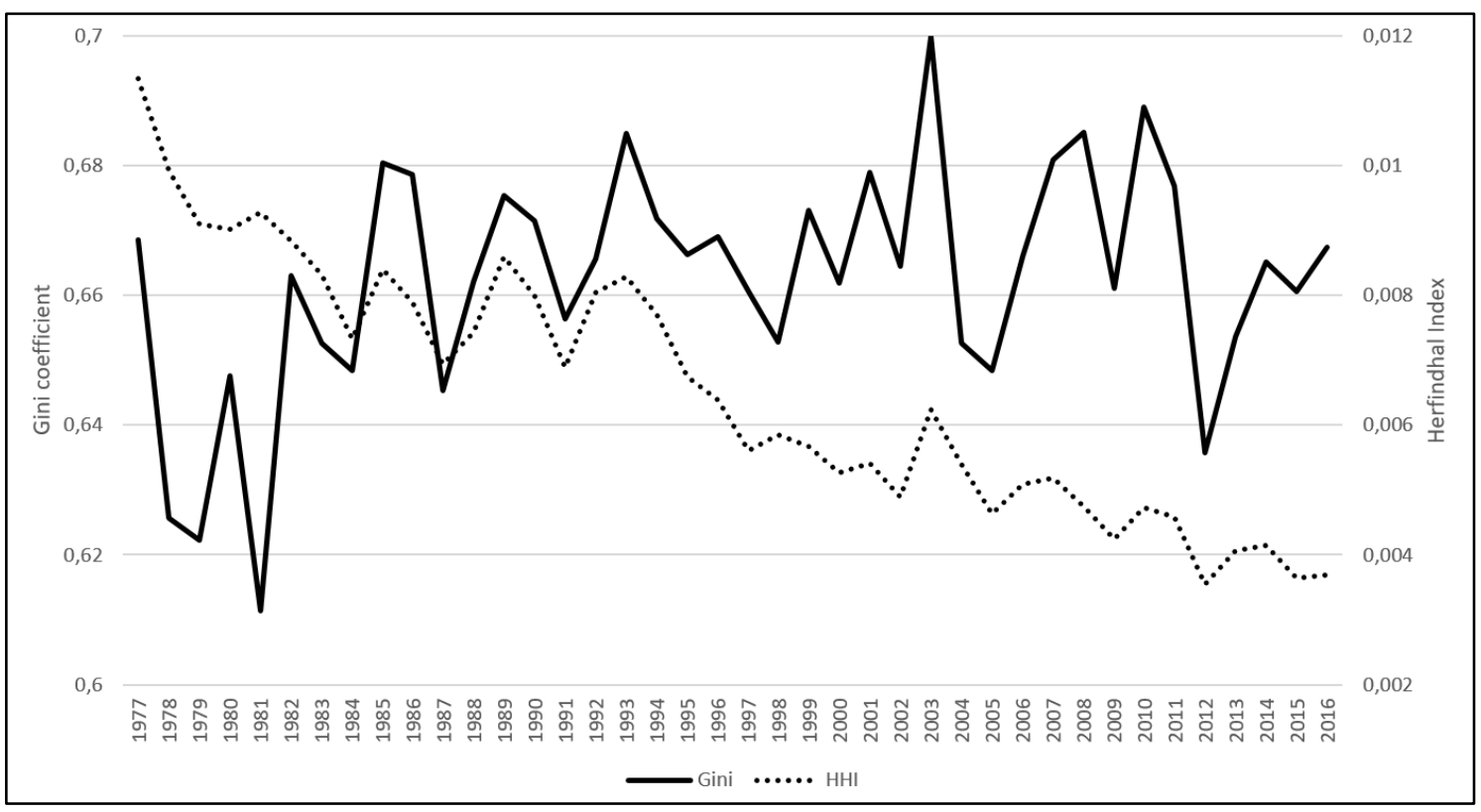

Figure 9: Global container network concentration, 1977-2016

Source: own elaboration based on Lloyd's List Intelligence data

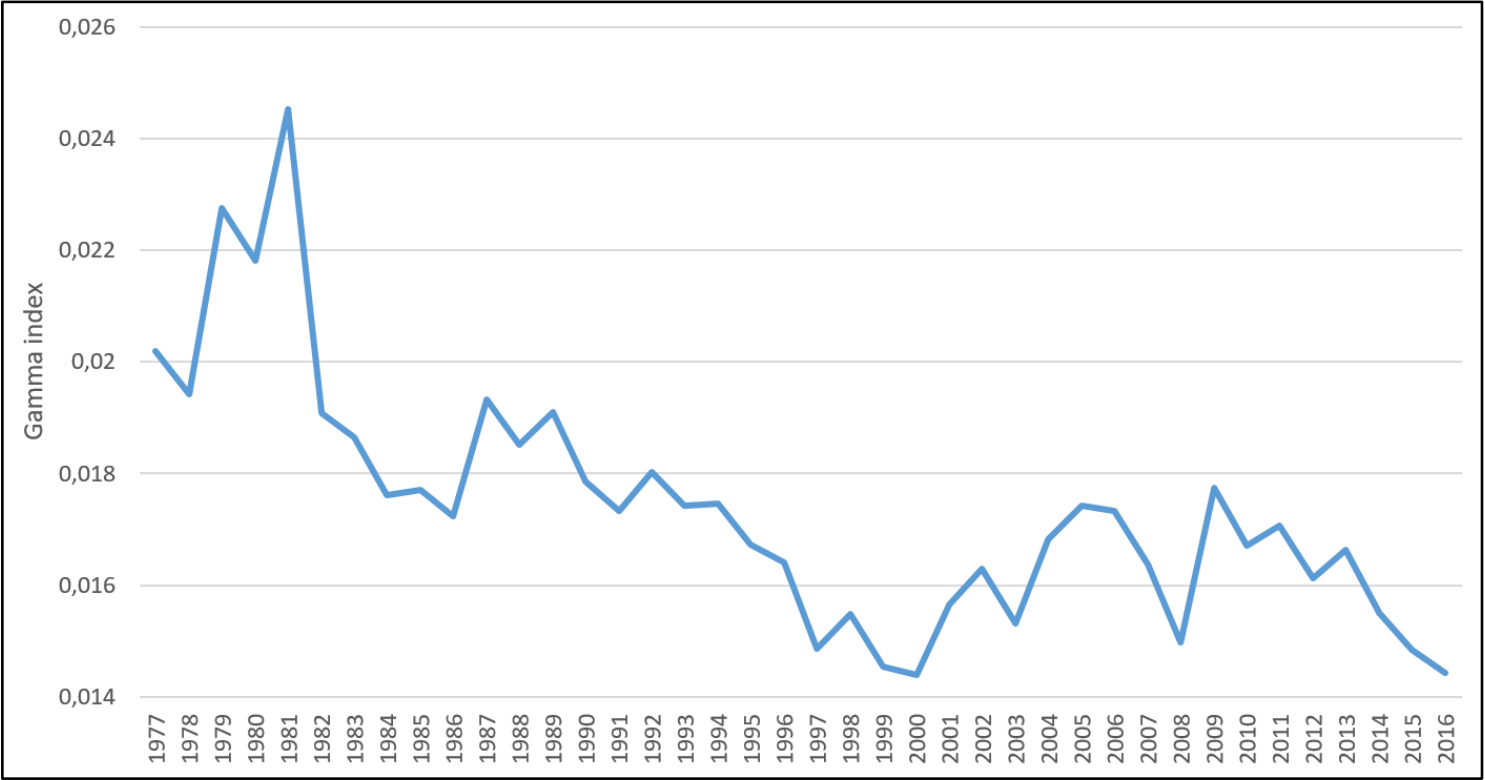




\section{Appendix:}

Table A1: Average growth rates by countries/regions

(a) Container handling volumes

\begin{tabular}{|c|c|c|c|c|c|c|c|c|}
\hline & $1975-1980$ & $1980-1985$ & $1985-1990$ & 1990-1995 & $1995-2000$ & $2000-2005$ & $2005-2010$ & 2010-2015 \\
\hline USA & $10.5 \%$ & $6.3 \%$ & $5.7 \%$ & $4.6 \%$ & $7.5 \%$ & $7.2 \%$ & $4.6 \%$ & $1.0 \%$ \\
\hline Canada & $12.1 \%$ & $7.5 \%$ & $7.2 \%$ & $3.1 \%$ & $16.3 \%$ & $7.4 \%$ & $3.2 \%$ & $4.0 \%$ \\
\hline Germany & $15.3 \%$ & $8.8 \%$ & $7.8 \%$ & $6.4 \%$ & $11.8 \%$ & $12.1 \%$ & $-0.2 \%$ & $9.3 \%$ \\
\hline Spain & $22.8 \%$ & $16.7 \%$ & $5.2 \%$ & $10.7 \%$ & $12.9 \%$ & $9.7 \%$ & $6.8 \%$ & $3.0 \%$ \\
\hline Netherlands & $12.6 \%$ & $6.2 \%$ & $6.5 \%$ & $5.4 \%$ & $5.7 \%$ & $8.3 \%$ & $4.2 \%$ & $2.1 \%$ \\
\hline Belgium & $13.7 \%$ & $10.3 \%$ & $5.3 \%$ & $8.8 \%$ & $12.1 \%$ & $9.4 \%$ & $7.5 \%$ & $0.4 \%$ \\
\hline Italy & $31.3 \%$ & $4.8 \%$ & $3.5 \%$ & $10.9 \%$ & $18.6 \%$ & $7.4 \%$ & $-0.1 \%$ & $1.0 \%$ \\
\hline UK & $10.5 \%$ & $5.1 \%$ & $7.0 \%$ & $3.2 \%$ & $6.7 \%$ & $5.6 \%$ & $1.8 \%$ & $5.8 \%$ \\
\hline France & $22.4 \%$ & $7.2 \%$ & $1.3 \%$ & $2.4 \%$ & $11.6 \%$ & $6.6 \%$ & $3.1 \%$ & $4.2 \%$ \\
\hline Sweden & $9.4 \%$ & $8.9 \%$ & $0.2 \%$ & $9.7 \%$ & $3.9 \%$ & $7.9 \%$ & $-0.5 \%$ & $3.4 \%$ \\
\hline Ireland & $8.2 \%$ & $1.9 \%$ & $7.6 \%$ & $8.8 \%$ & $9.4 \%$ & $6.2 \%$ & $-3.7 \%$ & $2.3 \%$ \\
\hline Denmark & $39.2 \%$ & $6.1 \%$ & $-1.4 \%$ & $4.4 \%$ & $4.5 \%$ & $14.4 \%$ & $-37.2 \%$ & $-1.0 \%$ \\
\hline China & $65.3 \%$ & $53.1 \%$ & $26.8 \%$ & $93.4 \%$ & $19.5 \%$ & $11.1 \%$ & $16.6 \%$ & $6.9 \%$ \\
\hline Hong Kong & $13.3 \%$ & $9.4 \%$ & $17.5 \%$ & $19.9 \%$ & $7.7 \%$ & $4.6 \%$ & $1.2 \%$ & $-3.0 \%$ \\
\hline Japan & $13.6 \%$ & $10.3 \%$ & $7.7 \%$ & $6.0 \%$ & $4.6 \%$ & $5.5 \%$ & $1.6 \%$ & $2.3 \%$ \\
\hline Korea & $32.8 \%$ & $13.3 \%$ & $13.9 \%$ & $14.1 \%$ & $15.0 \%$ & $11.1 \%$ & $4.5 \%$ & $6.6 \%$ \\
\hline Taiwan & $28.8 \%$ & $13.8 \%$ & $12.7 \%$ & $7.6 \%$ & $-20.9 \%$ & $4.1 \%$ & $0.6 \%$ & $2.5 \%$ \\
\hline Singapore & $33.2 \%$ & $13.3 \%$ & $25.3 \%$ & $17.8 \%$ & $7.6 \%$ & $6.6 \%$ & $5.2 \%$ & $1.8 \%$ \\
\hline Malaysia & $21.2 \%$ & $18.1 \%$ & $18.2 \%$ & $18.6 \%$ & $17.8 \%$ & $22.0 \%$ & $8.5 \%$ & $5.7 \%$ \\
\hline Indonesia & $49.2 \%$ & $23.6 \%$ & $33.5 \%$ & $17.4 \%$ & $18.4 \%$ & $7.9 \%$ & $11.0 \%$ & $8.4 \%$ \\
\hline Thailand & $94.7 \%$ & $16.3 \%$ & $22.0 \%$ & $12.8 \%$ & $10.4 \%$ & $10.0 \%$ & $5.4 \%$ & $5.1 \%$ \\
\hline Vietnam & & & & & & $16.8 \%$ & $18.7 \%$ & $8.7 \%$ \\
\hline Philippines & $36.3 \%$ & $8.8 \%$ & $17.2 \%$ & $8.3 \%$ & $10.4 \%$ & $3.7 \%$ & $7.5 \%$ & $7.3 \%$ \\
\hline India & $224.8 \%$ & $22.9 \%$ & $12.0 \%$ & $15.1 \%$ & $12.6 \%$ & $15.3 \%$ & $13.1 \%$ & $5.6 \%$ \\
\hline Brazil & $74.7 \%$ & $31.6 \%$ & $3.1 \%$ & $16.0 \%$ & $12.8 \%$ & $19.9 \%$ & $5.1 \%$ & $6.4 \%$ \\
\hline Australia & $10.4 \%$ & $3.7 \%$ & $4.1 \%$ & $6.9 \%$ & $9.3 \%$ & $8.0 \%$ & $4.9 \%$ & $3.4 \%$ \\
\hline Turkey & & $117.7 \%$ & $15.2 \%$ & $16.3 \%$ & $42.1 \%$ & $16.3 \%$ & $14.1 \%$ & $7.4 \%$ \\
\hline UAE & $58.7 \%$ & $16.6 \%$ & $17.6 \%$ & $17.9 \%$ & $27.2 \%$ & $14.6 \%$ & $9.7 \%$ & $7.1 \%$ \\
\hline Saudi Arabia & $80.9 \%$ & $3.8 \%$ & $-3.4 \%$ & $7.7 \%$ & $6.7 \%$ & $75.1 \%$ & $7.5 \%$ & $8.2 \%$ \\
\hline
\end{tabular}

(Note) West Germany and East Germany are integrated as Germany before 1990. And, Hong Kong is excluded in China for constant discussion.

(b) Gross Domestic Products (GDP)

\begin{tabular}{|c|c|c|c|c|c|c|c|c|c|}
\hline & $1970-1975$ & $1975-1980$ & $1980-1985$ & $\begin{array}{l}1985-1990 \\
\end{array}$ & $1990-1995$ & $1995-2000$ & $2000-2005$ & $2005-2010$ & $2010-2015$ \\
\hline USA & $2.7 \%$ & $3.7 \%$ & $3.4 \%$ & $3.4 \%$ & $2.6 \%$ & $4.3 \%$ & $2.5 \%$ & $0.8 \%$ & $2.2 \%$ \\
\hline Canada & $4.4 \%$ & $3.7 \%$ & $2.7 \%$ & $2.6 \%$ & $1.7 \%$ & $4.0 \%$ & $2.6 \%$ & $1.2 \%$ & $2.2 \%$ \\
\hline Germany & $2.4 \%$ & $3.4 \%$ & $1.4 \%$ & $3.3 \%$ & $2.1 \%$ & $1.9 \%$ & $0.6 \%$ & $1.3 \%$ & $1.7 \%$ \\
\hline Spain & $5.3 \%$ & $2.0 \%$ & $1.4 \%$ & $4.5 \%$ & $1.5 \%$ & $4.1 \%$ & $3.4 \%$ & $1.1 \%$ & $-0.2 \%$ \\
\hline Netherlands & $3.3 \%$ & $2.6 \%$ & $1.1 \%$ & $3.4 \%$ & $2.3 \%$ & $4.3 \%$ & $1.3 \%$ & $1.3 \%$ & $0.8 \%$ \\
\hline Belgium & $3.7 \%$ & $3.2 \%$ & $0.9 \%$ & $3.1 \%$ & $1.6 \%$ & $2.9 \%$ & $1.8 \%$ & $1.4 \%$ & $1.0 \%$ \\
\hline Italy & $3.2 \%$ & $4.5 \%$ & $1.7 \%$ & $3.1 \%$ & $1.3 \%$ & $2.0 \%$ & $0.9 \%$ & $-0.3 \%$ & $-0.6 \%$ \\
\hline UK & $2.1 \%$ & $2.3 \%$ & $2.4 \%$ & $3.5 \%$ & $1.6 \%$ & $3.3 \%$ & $2.8 \%$ & $0.4 \%$ & $2.1 \%$ \\
\hline France & $3.9 \%$ & $3.4 \%$ & $1.6 \%$ & $3.4 \%$ & $1.3 \%$ & $2.9 \%$ & $1.7 \%$ & $0.8 \%$ & $1.0 \%$ \\
\hline Sweden & $2.6 \%$ & $1.4 \%$ & $2.0 \%$ & $2.4 \%$ & $0.7 \%$ & $3.6 \%$ & $2.6 \%$ & $1.7 \%$ & $2.1 \%$ \\
\hline Ireland & $4.9 \%$ & $4.6 \%$ & $2.6 \%$ & $4.7 \%$ & $4.7 \%$ & $9.4 \%$ & $5.6 \%$ & $0.8 \%$ & $7.7 \%$ \\
\hline Denmark & $1.7 \%$ & $2.7 \%$ & $2.8 \%$ & $1.5 \%$ & $2.3 \%$ & $3.0 \%$ & $1.3 \%$ & $0.3 \%$ & $1.1 \%$ \\
\hline China & $5.9 \%$ & $6.6 \%$ & $10.7 \%$ & $8.0 \%$ & $12.3 \%$ & $8.6 \%$ & $9.8 \%$ & $11.3 \%$ & $7.9 \%$ \\
\hline Hong Kong & $6.6 \%$ & $11.6 \%$ & $5.8 \%$ & $7.8 \%$ & $5.3 \%$ & $2.7 \%$ & $4.3 \%$ & $4.0 \%$ & $3.0 \%$ \\
\hline Japan & $4.6 \%$ & $4.4 \%$ & $4.3 \%$ & $5.0 \%$ & $1.6 \%$ & $1.1 \%$ & $1.2 \%$ & $0.2 \%$ & $1.0 \%$ \\
\hline Korea & $10.0 \%$ & $8.6 \%$ & $9.4 \%$ & $10.5 \%$ & $8.4 \%$ & $5.7 \%$ & $4.7 \%$ & $4.1 \%$ & $3.0 \%$ \\
\hline \multicolumn{10}{|l|}{ Taiwan } \\
\hline Singapore & $9.6 \%$ & $8.6 \%$ & $6.9 \%$ & $8.7 \%$ & $8.7 \%$ & $5.7 \%$ & $4.9 \%$ & $6.9 \%$ & $4.1 \%$ \\
\hline Malaysia & $7.2 \%$ & $8.6 \%$ & $5.2 \%$ & $6.9 \%$ & $9.5 \%$ & $5.0 \%$ & $4.8 \%$ & $4.6 \%$ & $5.3 \%$ \\
\hline Indonesia & $7.0 \%$ & $7.9 \%$ & $4.8 \%$ & $6.3 \%$ & $7.1 \%$ & $1.0 \%$ & $4.7 \%$ & $5.7 \%$ & $5.5 \%$ \\
\hline Thailand & $5.8 \%$ & $8.0 \%$ & $5.4 \%$ & $10.3 \%$ & $8.2 \%$ & $0.9 \%$ & $5.5 \%$ & $3.8 \%$ & $2.9 \%$ \\
\hline Vietnam & & & $3.8 \%$ & $4.8 \%$ & $8.2 \%$ & $7.0 \%$ & $6.9 \%$ & $6.3 \%$ & $5.9 \%$ \\
\hline Philippines & $5.8 \%$ & $6.1 \%$ & $-1.1 \%$ & $4.7 \%$ & $2.2 \%$ & $3.6 \%$ & $4.6 \%$ & $5.0 \%$ & $5.9 \%$ \\
\hline India & $2.9 \%$ & $3.2 \%$ & $5.2 \%$ & $6.0 \%$ & $5.1 \%$ & $6.1 \%$ & $6.7 \%$ & $8.3 \%$ & $6.8 \%$ \\
\hline Brazil & $10.3 \%$ & $6.7 \%$ & $1.2 \%$ & $2.3 \%$ & $3.1 \%$ & $2.1 \%$ & $2.9 \%$ & $4.5 \%$ & $1.1 \%$ \\
\hline Australia & $3.2 \%$ & $2.8 \%$ & $2.9 \%$ & $4.0 \%$ & $2.4 \%$ & $4.2 \%$ & $3.2 \%$ & $2.8 \%$ & $2.7 \%$ \\
\hline Turkey & $5.8 \%$ & $2.5 \%$ & $4.9 \%$ & $5.7 \%$ & $3.3 \%$ & $4.1 \%$ & $4.9 \%$ & $3.4 \%$ & $7.1 \%$ \\
\hline UAE & & $16.2 \%$ & $-1.3 \%$ & $3.3 \%$ & $3.8 \%$ & $5.6 \%$ & $5.4 \%$ & $2.5 \%$ & $4.9 \%$ \\
\hline Saudi Arabia & $15.0 \%$ & $7.5 \%$ & $-9.9 \%$ & $7.6 \%$ & $3.7 \%$ & $1.7 \%$ & $4.1 \%$ & $2.8 \%$ & $5.2 \%$ \\
\hline
\end{tabular}

(Note) The GDP data of Taiwan is not available on the World Bank Open Data. 
Table A2: The relative shares for global total by countries/regions

(a) Container handling volumes

\begin{tabular}{|c|c|c|c|c|c|c|c|c|c|}
\hline & 1975 & 1980 & 1985 & 1990 & 1995 & 2000 & 2005 & 2010 & 2015 \\
\hline USA & $30.3 \%$ & $23.1 \%$ & $20.6 \%$ & $17.8 \%$ & $13.9 \%$ & $11.8 \%$ & $9.8 \%$ & $8.3 \%$ & $7.0 \%$ \\
\hline Canada & $2.5 \%$ & $2.0 \%$ & $1.9 \%$ & $1.8 \%$ & $1.3 \%$ & $1.3 \%$ & $1.1 \%$ & $0.9 \%$ & $0.8 \%$ \\
\hline Germany & $4.2 \%$ & $4.0 \%$ & $4.0 \%$ & $3.8 \%$ & $3.2 \%$ & $3.3 \%$ & $3.5 \%$ & $2.3 \%$ & $2.8 \%$ \\
\hline Spain & $1.5 \%$ & $1.9 \%$ & $2.7 \%$ & $2.3 \%$ & $2.3 \%$ & $2.5 \%$ & $2.3 \%$ & $2.3 \%$ & $2.1 \%$ \\
\hline Netherlands & $6.5 \%$ & $5.5 \%$ & $5.0 \%$ & $4.4 \%$ & $3.6 \%$ & $2.8 \%$ & $2.4 \%$ & $2.1 \%$ & $1.8 \%$ \\
\hline Belgium & $2.8 \%$ & $2.5 \%$ & $2.6 \%$ & $2.2 \%$ & $2.1 \%$ & $2.2 \%$ & $2.0 \%$ & $2.0 \%$ & $1.6 \%$ \\
\hline Italy & $1.8 \%$ & $3.3 \%$ & $2.7 \%$ & $2.1 \%$ & $2.2 \%$ & $3.0 \%$ & $2.5 \%$ & $1.8 \%$ & $1.5 \%$ \\
\hline UK & $8.0 \%$ & $6.1 \%$ & $5.2 \%$ & $4.7 \%$ & $3.4 \%$ & $2.8 \%$ & $2.1 \%$ & $1.5 \%$ & $1.6 \%$ \\
\hline France & $2.3 \%$ & $2.9 \%$ & $2.7 \%$ & $1.8 \%$ & $1.2 \%$ & $1.3 \%$ & $1.0 \%$ & $0.8 \%$ & $0.8 \%$ \\
\hline Sweden & $1.2 \%$ & $0.8 \%$ & $0.8 \%$ & $0.6 \%$ & $0.5 \%$ & $0.4 \%$ & $0.3 \%$ & $0.2 \%$ & $0.2 \%$ \\
\hline Ireland & $1.2 \%$ & $0.6 \%$ & $0.5 \%$ & $0.4 \%$ & $0.4 \%$ & $0.3 \%$ & $0.2 \%$ & $0.1 \%$ & $0.1 \%$ \\
\hline Denmark & $1.2 \%$ & $0.9 \%$ & $0.8 \%$ & $0.4 \%$ & $0.3 \%$ & $0.2 \%$ & $0.2 \%$ & $0.1 \%$ & $0.1 \%$ \\
\hline China & $0.0 \%$ & $0.1 \%$ & $0.8 \%$ & $1.4 \%$ & $12.6 \%$ & $17.7 \%$ & $17.2 \%$ & $25.4 \%$ & $28.3 \%$ \\
\hline Hong Kong & $4.6 \%$ & $3.9 \%$ & $4.1 \%$ & $6.0 \%$ & $9.1 \%$ & $7.8 \%$ & $5.8 \%$ & $4.3 \%$ & $2.9 \%$ \\
\hline Japan & $10.7 \%$ & $9.2 \%$ & $9.9 \%$ & $9.3 \%$ & $7.7 \%$ & $5.7 \%$ & $4.4 \%$ & $3.3 \%$ & $2.9 \%$ \\
\hline Korea & $1.1 \%$ & $1.8 \%$ & $2.2 \%$ & $2.7 \%$ & $3.3 \%$ & $3.9 \%$ & $3.9 \%$ & $3.4 \%$ & $3.7 \%$ \\
\hline Taiwan & $2.7 \%$ & $4.4 \%$ & $5.5 \%$ & $6.4 \%$ & $5.7 \%$ & $4.5 \%$ & $3.3 \%$ & $2.4 \%$ & $2.1 \%$ \\
\hline Singapore & $1.3 \%$ & $2.5 \%$ & $3.0 \%$ & $6.1 \%$ & $8.6 \%$ & $7.4 \%$ & $5.9 \%$ & $5.3 \%$ & $4.6 \%$ \\
\hline Malaysia & $0.4 \%$ & $0.5 \%$ & $0.7 \%$ & $1.0 \%$ & $1.5 \%$ & $2.0 \%$ & $3.1 \%$ & $3.3 \%$ & $3.5 \%$ \\
\hline Indonesia & $0.0 \%$ & $0.2 \%$ & $0.4 \%$ & $1.1 \%$ & $1.5 \%$ & $1.6 \%$ & $1.4 \%$ & $1.5 \%$ & $1.7 \%$ \\
\hline Thailand & $0.1 \%$ & $0.5 \%$ & $0.7 \%$ & $1.3 \%$ & $1.4 \%$ & $1.4 \%$ & $1.3 \%$ & $1.2 \%$ & $1.2 \%$ \\
\hline Vietnam & $0.0 \%$ & $0.0 \%$ & $0.0 \%$ & $0.0 \%$ & $0.0 \%$ & $0.5 \%$ & $0.6 \%$ & $1.1 \%$ & $1.3 \%$ \\
\hline Philippines & $0.5 \%$ & $1.2 \%$ & $1.1 \%$ & $1.6 \%$ & $1.4 \%$ & $1.3 \%$ & $0.9 \%$ & $0.9 \%$ & $1.0 \%$ \\
\hline India & $0.0 \%$ & $0.4 \%$ & $0.7 \%$ & $0.8 \%$ & $1.0 \%$ & $1.1 \%$ & $1.3 \%$ & $1.7 \%$ & $1.7 \%$ \\
\hline Brazil & $0.3 \%$ & $0.4 \%$ & $1.1 \%$ & $0.8 \%$ & $1.0 \%$ & $1.0 \%$ & $1.4 \%$ & $1.3 \%$ & $1.4 \%$ \\
\hline Australia & $4.3 \%$ & $3.2 \%$ & $2.5 \%$ & $1.9 \%$ & $1.7 \%$ & $1.5 \%$ & $1.3 \%$ & $1.2 \%$ & $1.1 \%$ \\
\hline Turkey & $0.0 \%$ & $0.0 \%$ & $0.3 \%$ & $0.4 \%$ & $0.5 \%$ & $0.7 \%$ & $0.8 \%$ & $1.1 \%$ & $1.2 \%$ \\
\hline UAE & $0.0 \%$ & $0.9 \%$ & $1.3 \%$ & $1.8 \%$ & $2.6 \%$ & $2.2 \%$ & $2.5 \%$ & $2.8 \%$ & $3.1 \%$ \\
\hline Saudi Arabia & $0.0 \%$ & $2.2 \%$ & $1.7 \%$ & $0.9 \%$ & $0.8 \%$ & $0.6 \%$ & $1.0 \%$ & $1.0 \%$ & $1.1 \%$ \\
\hline Others & $10.5 \%$ & $14.9 \%$ & $14.4 \%$ & $14.1 \%$ & $5.1 \%$ & $7.2 \%$ & $16.4 \%$ & $16.6 \%$ & $16.5 \%$ \\
\hline
\end{tabular}

(Note) West Germany and East Germany are integrated as Germany before 1990. And, Hong Kong is excluded in China for constant discussion.

(b) Gross Domestic Products (GDP)

\begin{tabular}{|c|c|c|c|c|c|c|c|c|c|}
\hline & 1975 & 1980 & 1985 & 1990 & 1995 & 2000 & 2005 & 2010 & 2015 \\
\hline USA & $23.7 \%$ & $23.5 \%$ & $24.3 \%$ & $23.9 \%$ & $24.4 \%$ & $25.4 \%$ & $24.8 \%$ & $22.7 \%$ & $22.0 \%$ \\
\hline Canada & $2.8 \%$ & $2.8 \%$ & $2.8 \%$ & $2.7 \%$ & $2.6 \%$ & $2.7 \%$ & $2.6 \%$ & $2.4 \%$ & $2.4 \%$ \\
\hline Germany & $7.5 \%$ & $7.3 \%$ & $6.9 \%$ & $6.8 \%$ & $6.7 \%$ & $6.2 \%$ & $5.5 \%$ & $5.2 \%$ & $4.9 \%$ \\
\hline Spain & $2.6 \%$ & $2.3 \%$ & $2.2 \%$ & $2.3 \%$ & $2.2 \%$ & $2.3 \%$ & $2.3 \%$ & $2.2 \%$ & $1.9 \%$ \\
\hline Netherlands & $1.6 \%$ & $1.5 \%$ & $1.4 \%$ & $1.4 \%$ & $1.4 \%$ & $1.5 \%$ & $1.4 \%$ & $1.3 \%$ & $1.2 \%$ \\
\hline Belgium & $1.0 \%$ & $1.0 \%$ & $0.9 \%$ & $0.9 \%$ & $0.8 \%$ & $0.8 \%$ & $0.8 \%$ & $0.7 \%$ & $0.7 \%$ \\
\hline Italy & $4.8 \%$ & $5.0 \%$ & $4.7 \%$ & $4.6 \%$ & $4.4 \%$ & $4.1 \%$ & $3.7 \%$ & $3.2 \%$ & $2.7 \%$ \\
\hline UK & $4.8 \%$ & $4.4 \%$ & $4.4 \%$ & $4.3 \%$ & $4.2 \%$ & $4.2 \%$ & $4.1 \%$ & $3.7 \%$ & $3.6 \%$ \\
\hline France & $5.5 \%$ & $5.4 \%$ & $5.1 \%$ & $5.0 \%$ & $4.8 \%$ & $4.7 \%$ & $4.4 \%$ & $4.0 \%$ & $3.7 \%$ \\
\hline Sweden & $1.1 \%$ & $0.9 \%$ & $0.9 \%$ & $0.8 \%$ & $0.8 \%$ & $0.8 \%$ & $0.8 \%$ & $0.7 \%$ & $0.7 \%$ \\
\hline Ireland & $0.2 \%$ & $0.2 \%$ & $0.2 \%$ & $0.2 \%$ & $0.2 \%$ & $0.3 \%$ & $0.4 \%$ & $0.3 \%$ & $0.4 \%$ \\
\hline Denmark & $0.7 \%$ & $0.7 \%$ & $0.7 \%$ & $0.6 \%$ & $0.6 \%$ & $0.6 \%$ & $0.5 \%$ & $0.5 \%$ & $0.5 \%$ \\
\hline China & $1.1 \%$ & $1.2 \%$ & $1.8 \%$ & $2.2 \%$ & $3.5 \%$ & $4.5 \%$ & $6.1 \%$ & $9.2 \%$ & $11.8 \%$ \\
\hline Hong Kong & $0.1 \%$ & $0.2 \%$ & $0.2 \%$ & $0.3 \%$ & $0.3 \%$ & $0.3 \%$ & $0.3 \%$ & $0.3 \%$ & $0.3 \%$ \\
\hline Japan & $10.4 \%$ & $10.7 \%$ & $11.6 \%$ & $12.4 \%$ & $12.0 \%$ & $10.7 \%$ & $9.8 \%$ & $8.6 \%$ & $7.9 \%$ \\
\hline Korea & $0.4 \%$ & $0.5 \%$ & $0.7 \%$ & $1.0 \%$ & $1.3 \%$ & $1.4 \%$ & $1.5 \%$ & $1.7 \%$ & $1.7 \%$ \\
\hline Taiwan & $0.0 \%$ & $0.0 \%$ & $0.0 \%$ & $0.0 \%$ & $0.0 \%$ & $0.0 \%$ & $0.0 \%$ & $0.0 \%$ & $0.0 \%$ \\
\hline Singapore & $0.1 \%$ & $0.1 \%$ & $0.1 \%$ & $0.2 \%$ & $0.2 \%$ & $0.3 \%$ & $0.3 \%$ & $0.4 \%$ & $0.4 \%$ \\
\hline Malaysia & $0.1 \%$ & $0.2 \%$ & $0.2 \%$ & $0.2 \%$ & $0.3 \%$ & $0.3 \%$ & $0.4 \%$ & $0.4 \%$ & $0.4 \%$ \\
\hline Indonesia & $0.5 \%$ & $0.7 \%$ & $0.7 \%$ & $0.8 \%$ & $1.0 \%$ & $0.9 \%$ & $1.0 \%$ & $1.1 \%$ & $1.3 \%$ \\
\hline Thailand & $0.2 \%$ & $0.2 \%$ & $0.3 \%$ & $0.4 \%$ & $0.5 \%$ & $0.4 \%$ & $0.5 \%$ & $0.5 \%$ & $0.5 \%$ \\
\hline Vietnam & $0.0 \%$ & $0.0 \%$ & $0.1 \%$ & $0.1 \%$ & $0.1 \%$ & $0.1 \%$ & $0.1 \%$ & $0.2 \%$ & $0.2 \%$ \\
\hline Philippines & $0.3 \%$ & $0.3 \%$ & $0.2 \%$ & $0.2 \%$ & $0.2 \%$ & $0.3 \%$ & $0.3 \%$ & $0.3 \%$ & $0.4 \%$ \\
\hline India & $1.0 \%$ & $1.0 \%$ & $1.1 \%$ & $1.2 \%$ & $1.4 \%$ & $1.6 \%$ & $1.9 \%$ & $2.5 \%$ & $3.0 \%$ \\
\hline Brazil & $3.2 \%$ & $3.6 \%$ & $3.4 \%$ & $3.1 \%$ & $3.3 \%$ & $3.1 \%$ & $3.1 \%$ & $3.3 \%$ & $3.1 \%$ \\
\hline Australia & $1.7 \%$ & $1.6 \%$ & $1.6 \%$ & $1.6 \%$ & $1.6 \%$ & $1.7 \%$ & $1.7 \%$ & $1.7 \%$ & $1.7 \%$ \\
\hline Turkey & $0.8 \%$ & $0.8 \%$ & $0.9 \%$ & $1.0 \%$ & $1.0 \%$ & $1.0 \%$ & $1.1 \%$ & $1.2 \%$ & $1.4 \%$ \\
\hline UAE & $0.2 \%$ & $0.4 \%$ & $0.3 \%$ & $0.3 \%$ & $0.4 \%$ & $0.4 \%$ & $0.4 \%$ & $0.4 \%$ & $0.5 \%$ \\
\hline Saudi Arabia & $1.1 \%$ & $1.3 \%$ & $0.7 \%$ & $0.8 \%$ & $0.8 \%$ & $0.8 \%$ & $0.8 \%$ & $0.8 \%$ & $0.9 \%$ \\
\hline Others & $22.3 \%$ & $22.3 \%$ & $21.6 \%$ & $20.6 \%$ & $18.6 \%$ & $18.5 \%$ & $19.3 \%$ & $20.2 \%$ & $19.8 \%$ \\
\hline
\end{tabular}

(Note) The GDP data of Taiwan is not available on the World Bank Open Data. 
Table 3: The changes of container ship sizes

\begin{tabular}{|c|c|c|c|c|c|c|c|c|c|}
\hline & 1 & 2 & 3 & 4 & 5 & 6 & 7 & 8 & 9 \\
\hline Category & Early & $\begin{array}{c}\text { Fully } \\
\text { Cellular }\end{array}$ & Panamax & $\begin{array}{c}\text { Panamax } \\
\text { Max }\end{array}$ & $\begin{array}{c}\text { Post } \\
\text { Panamax }\end{array}$ & $\begin{array}{c}\text { Post } \\
\text { Panamax II }\end{array}$ & $\begin{array}{c}\text { New- } \\
\text { Panamax }\end{array}$ & $\begin{array}{c}\text { VLCS } \\
\text { (very large) }\end{array}$ & $\begin{array}{c}\text { ULCS } \\
\text { (ultra large) }\end{array}$ \\
\hline Year & 1956- & $1970 \mathrm{~s}$ & 1980 & $1985-$ & 1988- & 2000- & 2014- & 2006- & 2013- \\
\hline Capacity & $500-800$ & $1,000-2,500$ & $3,000-3,400$ & $3,400-4,500$ & $4,000-6,000$ & $6,000-8,500$ & 12,500 & $\begin{array}{l}11,000- \\
15,000\end{array}$ & $\begin{array}{l}18,000- \\
21,000\end{array}$ \\
\hline Length(m) & 200 & 215 & 250 & 290 & 300 & 340 & 366 & 397 & 400 \\
\hline $\operatorname{Beam}(\mathrm{m})$ & 20 & 20 & 32 & 32 & 40 & 43 & 49 & 56 & 59 \\
\hline $\operatorname{Draft}(\mathrm{m})$ & 9 & 10 & 12.5 & 12.5 & 13 & 14.5 & 15.2 & 15.5 & 16 \\
\hline High * & $4(4)$ & $5(4)$ & $6(5)$ & $8(6)$ & $9(5)$ & $9(6)$ & $10(6)$ & $10(8)$ & $10(8)$ \\
\hline
\end{tabular}

(Note) $*$ High is the number of container high on deck, the number in parenthesis is below deck.

(Source) Rodrigue (2017).

\section{Table 4: The classification of port management organization and operational form}

\begin{tabular}{|c|c|c|c|c|c|c|c|c|}
\hline & & & \multirow{3}{*}{\begin{tabular}{|l} 
1. Government \\
Port manager
\end{tabular}} & \multicolumn{2}{|c|}{ 2. Leased home } & \multirow{2}{*}{\multicolumn{2}{|c|}{ 3. Term-leased land }} & \multirow{3}{*}{$\begin{array}{l}\text { 4. Ownership } \\
\text { Operator }\end{array}$} \\
\hline & & & & \multirow{2}{*}{$\begin{array}{l}\text { With equipment } \\
\text { Port manager }\end{array}$} & \multirow{2}{*}{$\begin{array}{l}\text { Without equipment } \\
\text { Port manager }\end{array}$} & & & \\
\hline \multicolumn{3}{|c|}{ development plan and permission } & & & & Port manager & Port manager & \\
\hline \multirow{2}{*}{ Construction } & Infra- & Non-profit & \multirow{2}{*}{ Port manager } & \multirow{2}{*}{ Port manager } & Port manager & Port manager & Port manager & \multirow{2}{*}{ Operator } \\
\hline & \multicolumn{2}{|c|}{ Super- } & & & Operator & Operator & Operator & \\
\hline \multirow{3}{*}{ Ownership } & \multicolumn{2}{|c|}{ Infra-non-profit } & \multirow{3}{*}{ Port manager } & \multirow{3}{*}{ Port manager } & \multirow{2}{*}{ Port manager } & \multirow{2}{*}{ Port manager } & Port manager & \multirow{3}{*}{ Operator } \\
\hline & \multirow{2}{*}{\multicolumn{2}{|c|}{$\begin{array}{l}\text { Infra-profit } \\
\text { Suner- }\end{array}$}} & & & & & Operator & \\
\hline & & & & & Operator & Operator & Operator & \\
\hline \multicolumn{3}{|l|}{ Example } & $\begin{array}{l}\text { Tanjung Priok } \\
\text { (Indonesia), Laem } \\
\text { Chabang } \\
\text { (Thailand), } \\
\text { Durban (South } \\
\text { Africa), Haifa } \\
\text { (Israel) }\end{array}$ & $\begin{array}{l}\text { Kaohsiung, } \\
\text { (Taiwan) Busan } \\
\text { (Korea), Japanese } \\
\text { major ports, } \\
\text { Seattle (USA), } \\
\text { Chinese ports, } \\
\text { Dubai (UAE) } \\
\end{array}$ & $\begin{array}{l}\text { European major } \\
\text { ports (Rotterdam, } \\
\text { Humbug), Los } \\
\text { Angeles, Long } \\
\text { Beach, NY/NJ } \\
\text { (USA) }\end{array}$ & Hong Kong & $\begin{array}{l}\text { Kaohsiung } \\
\text { (Taiwan), Busan } \\
\text { (Korea), Leam } \\
\text { Chabang } \\
\text { (Thailand), } \\
\text { Jawaharlal Nehru } \\
\text { Port (India) } \\
\end{array}$ & $\begin{array}{l}\text { Singapore, UK, } \\
\text { New Zealand }\end{array}$ \\
\hline
\end{tabular}

(Source) Kurihara (2014). 